\title{
Genome-wide transcriptional analysis suggests hydrogenase- and nitrogenase-mediated hydrogen production in Clostridium butyricum CWBI 1009
}

Magdalena Calusinska ${ }^{1,5+}{ }^{+}$, Christopher Hamilton ${ }^{2+}$, Pieter Monsieurs ${ }^{3+}$, Gregory Mathy ${ }^{4}$, Natalie Leys ${ }^{3}$, Fabrice Franck ${ }^{4}$, Bernard Joris ${ }^{1}$, Philippe Thonart ${ }^{2}$, Serge Hiligsmann ${ }^{2}$ and Annick Wilmotte ${ }^{1^{*}}$

\begin{abstract}
Background: Molecular hydrogen, given its pollution-free combustion, has great potential to replace fossil fuels in future transportation and energy production. However, current industrial hydrogen production processes, such as steam reforming of methane, contribute significantly to the greenhouse effect. Therefore alternative methods, in particular the use of fermentative microorganisms, have attracted scientific interest in recent years. However the low overall yield obtained is a major challenge in biological $\mathrm{H}_{2}$ production. Thus, a thorough and detailed understanding of the relationships between genome content, gene expression patterns, pathway utilisation and metabolite synthesis is required to optimise the yield of biohydrogen production pathways.

Results: In this study transcriptomic and proteomic analyses of the hydrogen-producing bacterium Clostridium butyricum CWBI 1009 were carried out to provide a biomolecular overview of the changes that occur when the metabolism shifts to $\mathrm{H}_{2}$ production. The growth, $\mathrm{H}_{2}$-production, and glucose-fermentation profiles were monitored in $20 \mathrm{~L}$ batch bioreactors under unregulated-pH and fixed-pH conditions (pH 7.3 and 5.2). Conspicuous differences were observed in the bioreactor performances and cellular metabolisms for all the tested metabolites, and they were $\mathrm{pH}$ dependent. During unregulated-pH glucose fermentation increased $\mathrm{H}_{2}$ production was associated with concurrent strong up-regulation of the nitrogenase coding genes. However, no such concurrent up-regulation of the [FeFe] hydrogenase genes was observed. During the fixed pH 5.2 fermentation, by contrast, the expression levels for the [FeFe] hydrogenase coding genes were higher than during the unregulated-pH fermentation, while the nitrogenase transcripts were less abundant. The overall results suggest, for the first time, that environmental factors may determine whether $\mathrm{H}_{2}$ production in C. butyricum CWBI 1009 is mediated by the hydrogenases and/or the nitrogenase.
\end{abstract}

Conclusions: This work, contributing to the field of dark fermentative hydrogen production, provides a multidisciplinary approach for the investigation of the processes involved in the molecular $\mathrm{H}_{2}$ metabolism of clostridia. In addition, it lays the groundwork for further optimisation of biohydrogen production pathways based on genetic engineering techniques.

Keywords: Dark fermentation, Clostridium butyricum, [FeFe] hydrogenase, Nitrogenase, RNA-seq, 2D-DIGE

\footnotetext{
* Correspondence: awilmotte@ulg.ac.be

'Equal contributors

${ }^{1}$ Centre for Protein Engineering, Bacterial Physiology and Genetics, University

of Liège, Allée de la Chimie 3, B-4000 Liège, Belgium

Full list of author information is available at the end of the article
}

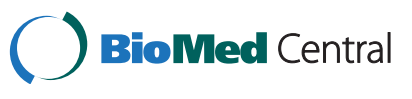

(c) 2015 Calusinska et al.; licensee BioMed Central. This is an Open Access article distributed under the terms of the Creative Commons Attribution License (http://creativecommons.org/licenses/by/4.0), which permits unrestricted use, distribution, and reproduction in any medium, provided the original work is properly credited. The Creative Commons Public Domain Dedication waiver (http://creativecommons.org/publicdomain/zero/1.0/) applies to the data made available in this article, unless otherwise stated. 


\section{Background}

Molecular hydrogen has great potential as a clean energy vector given its pollution-free combustion and the ease with which it can be converted into electricity via fuel cells. However, current industrial hydrogen production processes, such as steam reforming of natural gas, release large quantities of $\mathrm{CO}_{2}$ and thereby contribute substantially to the greenhouse effect [1]. Consequently, scientific interest in recent years has focused on alternative methods of hydrogen production, in particular on the use of photosynthetic and fermentative microorganisms for $\mathrm{CO}_{2}$-neutral $\mathrm{H}_{2}$ production from renewable energy sources, such as solar energy and biomass [2]. Nevertheless, a major challenge when using microorganisms for $\mathrm{H}_{2}$ production is the low yield generally obtained, with typical mesophilic fermentation of carbohydrates supplying only 10 to $20 \%$ of the $\mathrm{H}_{2}$ potentially available in the substrate. Consequently, research in the field of metabolic engineering has investigated different approaches with a view to optimising the yield of well-characterised biohydrogen production pathways [3]. However, such strategies require a thorough and detailed understanding of the relationships between genome content, gene expression patterns, pathway utilisation and metabolite synthesis.

In dark anaerobic fermentation microorganisms break down carbohydrate-rich substrates into organic acids and alcohols while releasing $\mathrm{H}_{2}$. Strict anaerobes such as clostridia have been the most widely studied among the various anaerobic and facultative anaerobic bacteria capable of fermentative hydrogen production [4]. $\mathrm{H}_{2}$ production in living organisms is always dependent on the presence of $\mathrm{H}_{2}$-producing enzymes such as hydrogenases and nitrogenases. [FeFe] hydrogenases, which are especially abundant in clostridia, are well recognised as the main $\mathrm{H}_{2}$-producing enzymes in this genus $[5,6]$. By contrast, nitrogenase-mediated hydrogen production has never been proposed for clostridia, even though this is known to be an intrinsic metabolic property of many cyanobacteria and photosynthetic bacteria [2]. Interestingly, in 1960 Carnahan showed that the free-living soil microorganism Clostridium pasteurianum is an efficient $\mathrm{N}_{2}$ fixator [7]. Later nif operons were described in C. acetobutylicum and C. beijerinckii [8], but the contribution of nitrogenase to overall $\mathrm{H}_{2}$ production in clostridia has not yet been reported in the literature.

Clostridium butyricum CWBI 1009, a strain recently isolated from an anaerobic sludge, was previously shown to ferment different carbon substrates at acidic $\mathrm{pH}$ to $\mathrm{H}_{2}$ and $\mathrm{CO}_{2}$ with formate, butyrate and acetate as the main end-products $[9,10]$. It possesses four different [FeFe] hydrogenases, three of which are monomeric belonging to clusters A2, B2 and B3, and one which is a trimeric enzyme representing cluster A8 [6,11]. Despite the fact that optimum growth for this bacterium occurs at $\mathrm{pH} 7.3$, it only starts to produce $\mathrm{H}_{2}$ when the $\mathrm{pH}$ declines due to the natural acidification of the medium as fermentation proceeds. The optimal $\mathrm{pH}$ value to produce $\mathrm{H}_{2}$ under fixed-pH culture conditions was found to be 5.2 and has been discussed in previous work [9]. Although many studies have described the fermentative activity of C. butyricum associated with $\mathrm{H}_{2}$ production $[12,13]$, a comprehensive analysis of the fermentative pathways at the genomic and proteomic levels has not yet been reported. Relative gene expression profiles, together with the associated proteomic and metabolite data, can now be used to provide the visibility needed for well-targeted metabolic engineering. Moreover, a better understanding of the shifts in gene and protein expression, which occur in response to $\mathrm{pH}$ changes and during the growth phase, should facilitate the optimisation of bioreactor performance.

Therefore, in this study three parallel approaches were used to investigate the changes at the molecular level associated with $\mathrm{pH}$-dependent hydrogen production in C. butyricum CWBI 1009, namely metabolite analysis, transcriptomics and proteomics. The effect of the naturally decreasing $\mathrm{pH}$ was studied with glucose in $20-\mathrm{L}$ batch bioreactors. Additionally, the effect of fixed-pH fermentations was evaluated to provide comparative data under optimal $\mathrm{pH}$ conditions for cellular growth ( $\mathrm{pH}$ 7.3) and $\mathrm{H}_{2}$ production ( $\mathrm{pH}$ 5.2), respectively. The genome of C. butyricum CWBI 1009, which was unknown until now, was also sequenced to provide better mapping of the RNA-sequencing (RNA-seq) reads during natural acidification of the medium. In addition the expression levels of the $\mathrm{H}_{2}$-producing enzymes, namely the $[\mathrm{FeFe}]$ hydrogenases and the nitrogenase, were determined under different $\mathrm{pH}$ conditions.

\section{Results and discussion Experimental design}

Three 20-L glucose fermentations were carried out under unregulated-pH conditions (Figure 1, A, D and G), allowing characterisation of the impact of naturally decreasing $\mathrm{pH}$ on fermentative $\mathrm{H}_{2}$ production by C. butyricum CWBI 1009. Additional glucose fermentations (three replicates for each condition) performed at two fixed $\mathrm{pH}$ values, namely 7.3 (Figure 1, B, E and $\mathrm{H}$ ) and 5.2 (Figure 1, C, F and I), were carried out to provide comparative data for the interpretation of the results obtained during the unregulated-pH fermentations. These fixed $\mathrm{pH}$ values of 7.3 and 5.2 were previously determined to be optimal for C. butyricum CWBI 1009 growth and $\mathrm{H}_{2}$ production, respectively [9]. The fermentation results presented below for the triplicated experiments were characterised by standard deviations ranging from 5 to $10 \%$ of the absolute value. Therefore, the reproducibility of the results may be 


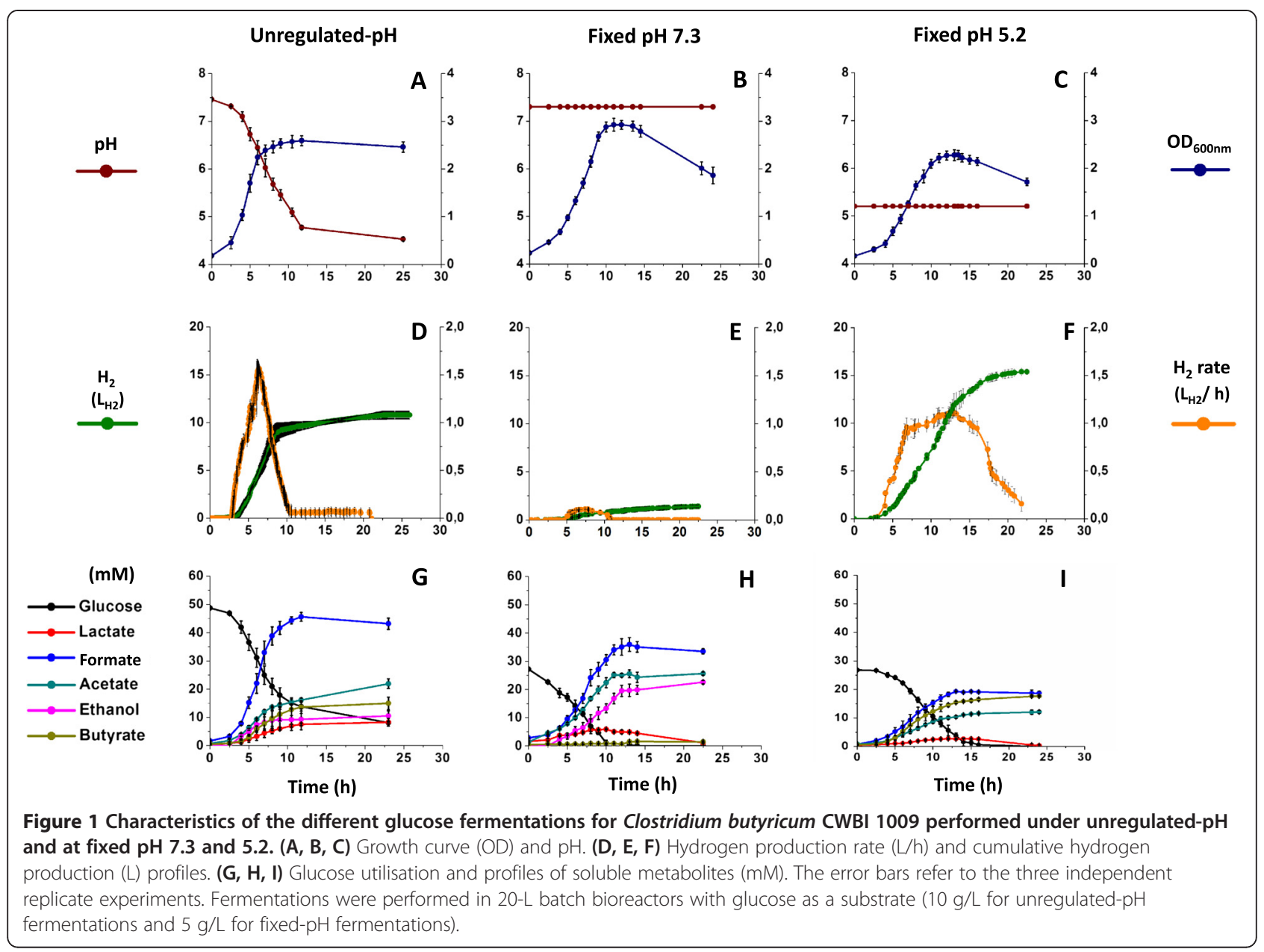

considered as sufficient and typical for these kinds of experiments in 20-L bioreactors.

For all the above fermentations, analyses were carried out to determine whether the $\mathrm{H}_{2}$ production and the cellular metabolism for all the tested metabolites varied and, if so, to what extent these variations were $\mathrm{pH}$ dependent. The genome-wide transcriptional response of C. butyricum CWBI 1009 to naturally decreasing $\mathrm{pH}$ (associated with increasing $\mathrm{H}_{2}$ production) was characterised during glucose fermentation without $\mathrm{pH}$ regulation. The gene expression levels of the $\mathrm{H}_{2}$-producing enzymes, namely the $[\mathrm{FeFe}]$ hydrogenases and the nitrogenase, were then examined, and the data were related to the $\mathrm{H}_{2}$ production profiles under the different conditions studied. Finally the proteomic response of $C$. butyricum CWBI 1009 to declining $\mathrm{pH}$ was analysed.

$\mathrm{H}_{2}$ and metabolite production under unregulated-pH and fixed $\mathrm{pH}$ conditions

The effect of naturally decreasing $\mathrm{pH}$ on the growth, $\mathrm{H}_{2}$-production and fermentation profiles of C. butyricum CWBI 1009 cultivated with glucose (10 g/L) was evaluated in a $20-\mathrm{L}$ batch anaerobic bioreactor maintained at $30^{\circ} \mathrm{C}$ and $\mathrm{N}_{2}$ atmosphere. The culture was monitored during the $25 \mathrm{~h}$ of fermentation by which time the $\mathrm{pH}$ had dropped naturally to about 4.5 (Figure 1A). Directly after the lag phase there was a rapid consumption of glucose and an increase in growth. In total 17.16 $\pm 0.84 \mathrm{~L}$ of biogas were produced. Given that the average $\mathrm{H}_{2}$ content of the biogas was $63 \pm 4 \%$, it was calculated that $10.80 \pm 0.44 \mathrm{~L}$ of $\mathrm{H}_{2}$ were produced (Additional file 1: Table S1). The highest $\mathrm{H}_{2}$ flow rate, $1.56 \pm 0.15 \mathrm{~L} \mathrm{H}_{2} / \mathrm{h}$, was recorded after 6 to $7 \mathrm{~h}$ of fermentation (Figure 1D) by which time the $\mathrm{pH}$ of the medium had dropped to around 6.3. The highest calculated $\mathrm{H}_{2}$ yield was $1.78 \pm 0.11 \mathrm{~mol} \mathrm{H}_{2} / \mathrm{mol}$ glucose. The primary soluble metabolites at the end of fermentation were formate, acetate and butyrate, followed by ethanol and lactate (Figure 1G).

To highlight the impact of $\mathrm{pH}$ on the gene expression for the $\mathrm{H}_{2}$-producing enzymes, that is, the hydrogenases and the nitrogenase, the comparative results for $\mathrm{H}_{2}$ and metabolite production with glucose $(5 \mathrm{~g} / \mathrm{L})$, using the same bioreactor, are briefly presented for two different fixed-pH conditions: $\mathrm{pH} 7.3$ and $5.2 \pm 0.15$. At fixed 
$\mathrm{pH} 7.3$ a lag phase of $3 \mathrm{~h}$ was observed (Figure 1B), compared to a lag phase of $4.5 \mathrm{~h}$ at fixed $\mathrm{pH} 5.2$ (Figure 1C). Exponential growth followed the lag phase under both $\mathrm{pH}$ conditions. At $\mathrm{pH} 7.3$ rapid consumption of glucose was observed (Figure $1 \mathrm{H}$ ), and the glucose uptake rate peaked at $0.96 \pm 0.08 \mathrm{~g}$ glucose $/ \mathrm{h}$. Biogas production started after $5.5 \mathrm{~h}$ of fermentation, yielding a total of $2.90 \pm 0.23 \mathrm{~L}$ of biogas after $15 \mathrm{~h}$ of fermentation (Additional file 1: Table S2). At pH 5.2, the glucose uptake rate was much lower $(0.44 \pm 0.03 \mathrm{~g}$ glucose $/ \mathrm{h})$ and biogas production had already started after $3.5 \mathrm{~h}$ of fermentation. After $20 \mathrm{~h}$ of fermentation a total of $23.32 \pm$ $1.01 \mathrm{~L}$ of biogas was produced. At $\mathrm{pH} 7.3$ the $\mathrm{H}_{2}$ production rate and yield peaked at $0.21 \mathrm{~L} \pm 0.03 \mathrm{H}_{2} / \mathrm{h}$ (Figure 1E) and $0.23 \pm 0.02 \mathrm{~mol} \mathrm{H}_{2} / \mathrm{mol}$ glucose, respectively. By contrast, at $\mathrm{pH} 5.2$ the corresponding $\mathrm{H}_{2}$ production rate and yield were much higher; $1.11 \mathrm{~L} \pm 0.06 \mathrm{H}_{2} / \mathrm{h}$ (Figure 1F) and $1.95 \pm 0.09 \mathrm{~mol} \mathrm{H}_{2} /$ mol glucose. The cellular metabolisms for all the tested metabolites varied between the unregulated-pH fermentations and those when the $\mathrm{pH}$ was fixed at 5.2 and 7.3. Moreover, the lactate produced during the early stages of fermentation was later consumed, which was not the case with the fermentations carried out under unregulated-pH conditions (Figure $1 \mathrm{H}$ and I). The ability of clostridia to reconsume lactate produced during the early stages of fermentation indicates the existence of novel metabolic pathways, an observation that has already been discussed in the literature [10].

\section{Transcriptional response of C. butyricum CWBI 1009 to decreasing $\mathrm{pH}$}

As an initial step towards understanding how the bacterium responds to naturally decreasing $\mathrm{pH}$, which is associated with increasing $\mathrm{H}_{2}$ production, the transcriptional response of C. butyricum CWBI 1009 was analysed during unregulated-pH glucose fermentation. The genome of C. butyricum CWBI 1009 was also sequenced to provide better mapping of the RNA-seq reads. The RNA-seq data were obtained from rRNA-depleted mRNA samples isolated from two independent reactor cultures (biological replicates). RNA-seq data were acquired from samples taken at $\mathrm{pH} 7.3$ (early exponential growth phase: control sample) and at pH 6.3 (late exponential growth phase: test samples), and are shown in Additional file 2: Table S4 and Additional file 3: Table S5. The selection of these values was based on the fact that $\mathrm{pH} 7.3$ and 6.3 corresponded respectively to the minimum and maximum $\mathrm{H}_{2}$ production phases of the three fermentations without $\mathrm{pH}$ regulation. Additionally, the gene expression profiles during the stationary phase, corresponding in this experiment to $\mathrm{pH} 5.2$, were analysed and are shown in Additional file 2: Table S4. The reproducibility of the transcriptomic data between the two biological replicates was high with an $\mathrm{R}^{2}$ ranging from 0.873 for the control sample $(\mathrm{pH} 7.3)$ to 0.78 for the samples taken at $\mathrm{pH} 6.3$ (Additional file 1: Figure S1). For each sample both the reads mapping to rRNA sequences and those not mapping uniquely to the genome of C. butyricum CWBI 1009 were omitted from further analysis (Additional file 1: Table S3). The RNA-seq expression data have been presented in two ways. Firstly, the total number of reads for each coding DNA sequence (CDS) was calculated and converted to reads per kilobase per million mapped reads (RPKM numbers), and secondly the genes that were differentially regulated between the stages corresponding to $\mathrm{pH} 6.3$ and 7.3 were identified (Figures 2 and 3).

Calculation of the RPKM enabled a comparison between the relative mRNA abundances of different genes for a given condition and also between the relative abundances of a specific gene under the different $\mathrm{pH}$ conditions. Based on the RPKM numbers, the genes coding for the glycolytic enzymes and the auxiliary proteins involved in the core metabolic reactions (for example, ferredoxin, NAD-dependent glyceraldehyde-3-phosphate dehydrogenase, pyruvate formate-lyase, acetaldehyde dehydrogenase, pyruvate kinase or flavodoxin) were among the most highly expressed, and their expression did not vary significantly throughout the fermentation (Additional file 2: Table S4). Unexpectedly, multiple genes encoding different subunits of the nitrogenase (for example, nif $N$, nifH, nifD, nifS) and the urease $(\alpha, \beta$ and $\gamma$ subunits) were also very highly expressed at $\mathrm{pH} 6.3$ (RPKM $\geq 500$ ). To our surprise the mRNA moieties of the $[\mathrm{FeFe}]$ hydrogenases were among the least abundant transcriptional units, which contrasts strongly with the increased $\mathrm{H}_{2}$ production associated with this fermentation stage (Figure 2).

RNA-seq data were also used to identify the genes that were significantly up- or down-regulated under the

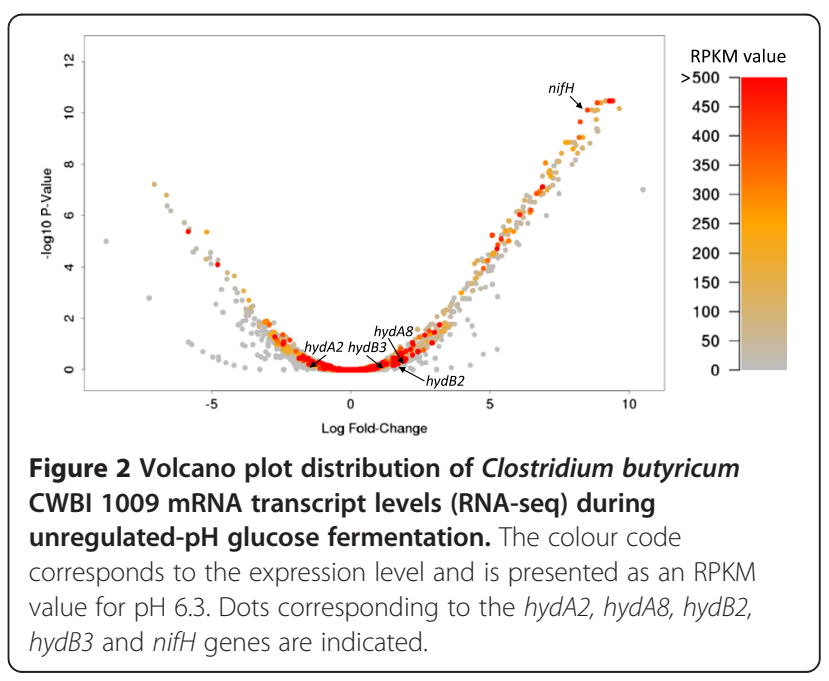




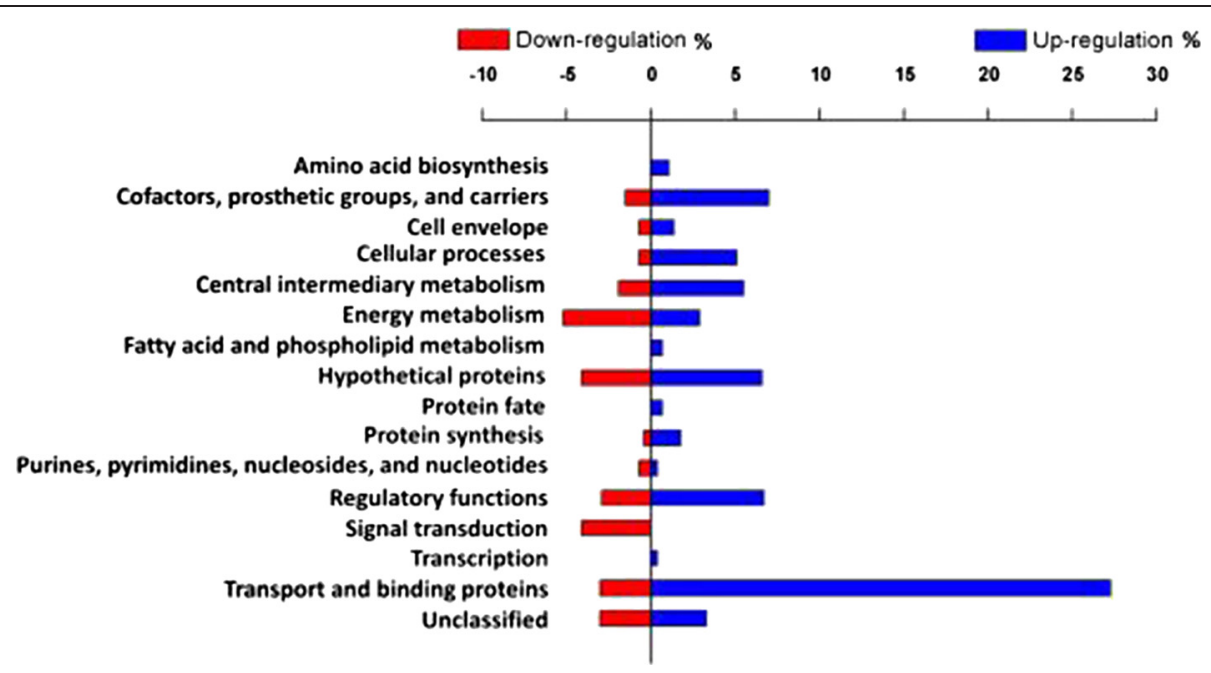

Figure 3 Differentially regulated pathways of Clostridium butyricum CWBI 1009 during unregulated-pH glucose fermentation based on the RNA-seq data ( $\mathrm{pH} 6.3$ versus $\mathrm{pH} 7.3$ ).

different $\mathrm{pH}$ conditions studied. The relative expression levels were presented as a fold change $\left(\log _{2}\right)$ between the control sample ( $\mathrm{pH}$ 7.3) and the test sample ( $\mathrm{pH}$ 6.3). In total more than 290 genes were found to be differentially expressed, with $72 \%$ being up-regulated and only $28 \%$ down-regulated at $\mathrm{pH} 6.3$ (Figure 3, Additional file 3: Table S5). Many of these genes were located in close proximity on the chromosome, and are therefore likely to represent polycistronic operons encoding proteins with similar functions. The differentially regulated genes were automatically assigned functional annotations using the Clusters of Orthologous Groups (COG) database; these annotations were then corrected based on the PathemaClostridium assigned categories (http://pathema.jcvi.org).

Over $30 \%$ of the annotated and differentially regulated transcripts were associated with transport proteins $(28 \%$ of which were up-regulated), suggesting that transport plays a crucial role in maintaining cell homeostasis at acidic $\mathrm{pH}$. Sequences linked to the biosynthesis of cofactors, prosthetic groups and carriers, as well as the central intermediary metabolism and regulatory function proteins were also found to be differentially regulated (Figure 3). Genes encoding for conserved hypothetical proteins constituted around $10 \%$ of all the differentially regulated genes, and a few of them had very high RPKM values at pH 6.3 (RPKM $\geq 1,000$, Additional file 2: Table S4), suggesting their importance for cell metabolism. In line with this result, Wang et al. [14] reported that many genes encoding for hypothetical proteins accounted for a large fraction of the highly expressed genes during the different stages of batch glucose fermentation by Clostridium beijerinckii NCIMB 8052. In addition, the genes coding for the proteins involved in protein folding and stabilisation, such as heat shock proteins, were not differentially expressed, but were nevertheless very highly expressed throughout the fermentation (RPKM $\geq$ 1,000 for dnaK, groEL and groES). For comparison, genes such as groESL, hsp 90 or dnaK were previously reported to be induced by acetate and butyrate shock in $C$. acetobutylicum [15] and also by butanol in this bacterium [16] and were confirmed as being important in the general stress response.

\section{Is $\mathrm{H}_{2}$ production under unregulated-pH conditions nitrogenase-mediated?}

The genome of C. butyricum CWBI 1009 encodes four [FeFe] hydrogenases. However, the RNA-seq analysis unexpectedly indicated that none of them showed any signs of being up-regulated at $\mathrm{pH} 6.3$, when the $\mathrm{H}_{2}$ production rate was maximum (Figure 2, Additional file 3: Table S5). Furthermore, this result was confirmed by RT-qPCR with hydrogenase-specific primers for each gene (Figure 4A and B, Additional file 1: Figure S2).

Surprisingly, the genes that were among the most strongly induced at $\mathrm{pH} 6.3$ included the genes encoding nitrogenase and other proteins related to $\mathrm{N}_{2}$ fixation, ammonium transport and molybdenum transport (Additional file 3: Table S5). The physiological electron donors for nitrogenases, ferredoxins (RPKM $>8,800)$ and flavodoxins (RPKM > 4,700) were also very highly abundant at $\mathrm{pH} 6.3$ (Additional file 2: Table S4). In addition various nitrogen regulatory P-II proteins were significantly up-regulated at $\mathrm{pH} 6.3$ and accounted for $30 \%$ of the regulatory factors that were differentially regulated between the two $\mathrm{pH}$ conditions studied (Additional file 4: Table S8).

Nitrogenase-mediated $\mathrm{H}_{2}$ production is a property of several microorganisms including cyanobacteria and photosynthetic bacteria [2], and has recently been revealed in marine 

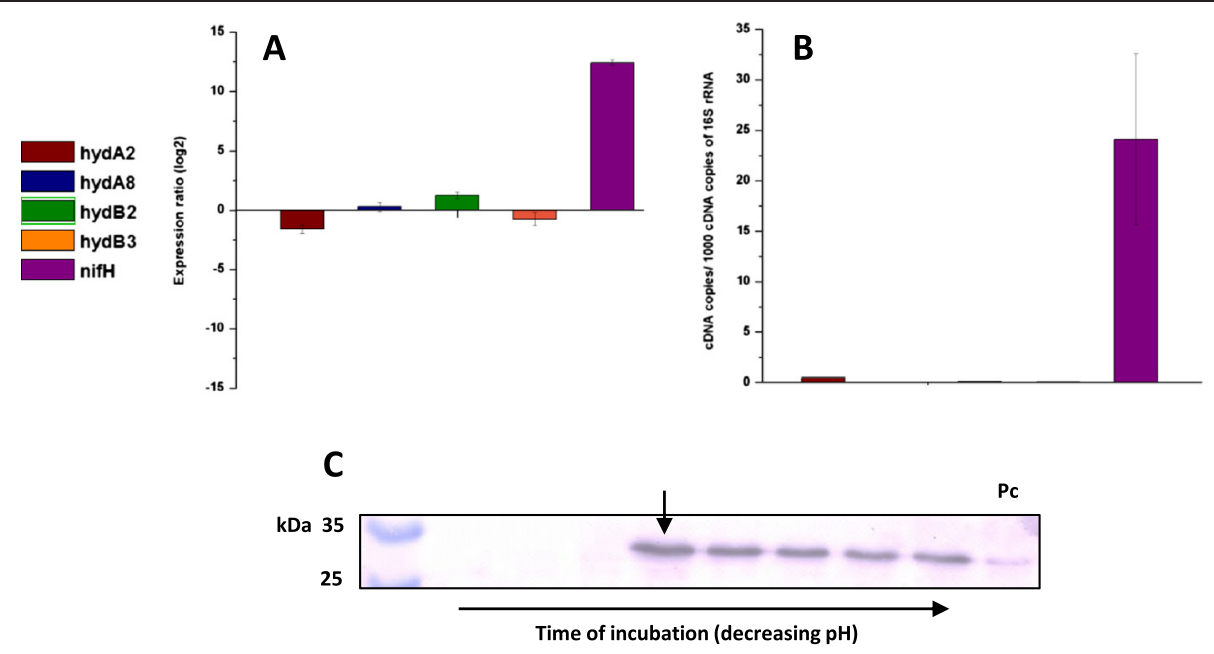

Figure 4 Relative expression of [FeFe] hydrogenases and nifH genes determined by RT-qPCR of Clostridium butyricum CWBI 1009 during unregulated-pH glucose fermentation. Western blot analysis for the NifH subunit. (A) Fold change in the expression level of hydA2, hydA8, hydB2, hydB3, nifH genes during the unregulated-pH glucose fermentation determined by RT-qPCR. The values correspond to the $\mathrm{pH} 6.3$ (test) sample) versus pH 7.3 (control) sample). (B) Basal expression levels of hydA2, hydA8, hydB2, hydB3, nifH gene transcripts during the unregulated-pH glucose fermentation. The values correspond to the late exponential growth stage that refers to the peak in $\mathrm{H}_{2}$ production at pH 6.3. Expression level is shown as number of cDNA copies per 1,000 CDNA copies of 165 rRNA. (C) Western blot analysis of the crude cellular extracts taken during the unregulated-pH glucose fermentation. Time of incubation corresponds to the different growth stages starting from the beginning of the experiment, until the pH dropped to a level of about 4.5. The arrow indicates pH 6.3. Pc: positive control.

Enterobacteriaceae, for example, Pantoea agglomerans [17]. However, it has never before been proposed for clostridia. Therefore, to validate the up-regulation of the nitrogenase genes, an RT-qPCR analysis was carried out for the nifH gene, which encodes a nitrogenase reductase subunit. The results showed a significant up-regulation of this gene at pH 6.3 and were in agreement with the RNA-seq results (Figure 4A, Additional file 1: Figure S2). Additionally, by using anti-NifH antibodies, the presence of the nitrogenase $\mathrm{H}$ subunit in crude cellular extracts was confirmed by Western blot analysis (Figure $4 \mathrm{C}$ ). Since the $\mathrm{H}_{2}$ production rate peaked at $1.56 \pm 0.15 \mathrm{~L} / \mathrm{h}$ at $\mathrm{pH} 6.3$ and was below $0.21 \pm 0.03 \mathrm{~L} / \mathrm{h}$ at $\mathrm{pH} 7.3$ (Figure $1 \mathrm{D}$ ), the very strong up-regulation of the nitrogenase coding genes at the lower $\mathrm{pH}$, combined with the concurrent absence of upregulation of the [FeFe] hydrogenase genes, led us to conclude that the $\mathrm{H}_{2}$ production in C. butyricum CWBI 1009 during glucose fermentation with unregulated- $\mathrm{pH}$ may be nitrogenase-mediated.

Interestingly, though nitrogenase is known to produce $\mathrm{H}_{2}$ as a by-product of $\mathrm{N}_{2}$ fixation, already in the early 1980 s it was reported that the enzyme may act as an ATP-powered hydrogenase and produce only $\mathrm{H}_{2}$ in the absence of $\mathrm{N}_{2}$ [18]. Therefore, to check if this was the case with clostridia, C. butyricum CWBI 1009 was cultured in an $\mathrm{N}_{2}$-free atmosphere with unregulated- $\mathrm{pH}$, using argon instead of nitrogen to initiate the anaerobic conditions in the bioreactor. The preliminary results demonstrated that, in contrast to the fermentation with unregulated- $\mathrm{pH}$ under $\mathrm{N}_{2}$, under an Ar atmosphere there was an induction of three [FeFe] hydrogenase genes (hydA8, hydB2 and hydB3) at low $\mathrm{pH}$ values (results discussed in Additional file 6). A better understanding of the differences between the mechanisms leading to $\mathrm{H}_{2}$ production under these two conditions would nevertheless require a more detailed analysis of the Ar sample at the transcriptomic and proteomic levels. Additionally, as a follow-up to the present work, a study of the physiological activity of the [FeFe] hydrogenases and the nitrogenase could be carried out to evaluate the exact contribution of each enzyme to the overall $\mathrm{H}_{2}$ production under different experimental conditions.

\section{The physiological function of hydrogen and ammonia- generating enzymes under unregulated-pH conditions may be to maintain the $\mathrm{pH}$ homeostasis of the cell}

$\mathrm{N}_{2}$ fixation (reduction of $\mathrm{N}_{2}$ to two ammonia molecules) is a highly energy-intensive process, consuming at least 16 ATP molecules per molecule of nitrogen fixed. It has been shown that while ammonium nitrogen can repress the formation of nitrogenase in different species [19], amino acid nitrogen can actually stimulate it (the main $\mathrm{N}$ source in this study was the amino acids contained in casein peptone and yeast extract) [20]. The release of molecular $\mathrm{H}_{2}$, a by-product of $\mathrm{N}_{2}$ fixation, enables the disposal of excess protons, thereby preventing acidification of the cytoplasm. Clearly proton disposal is the main physiological function of [FeFe] hydrogenases, but in this case nitrogenase activity may provide an additional buffering molecule, namely ammonia (Figure 5). 


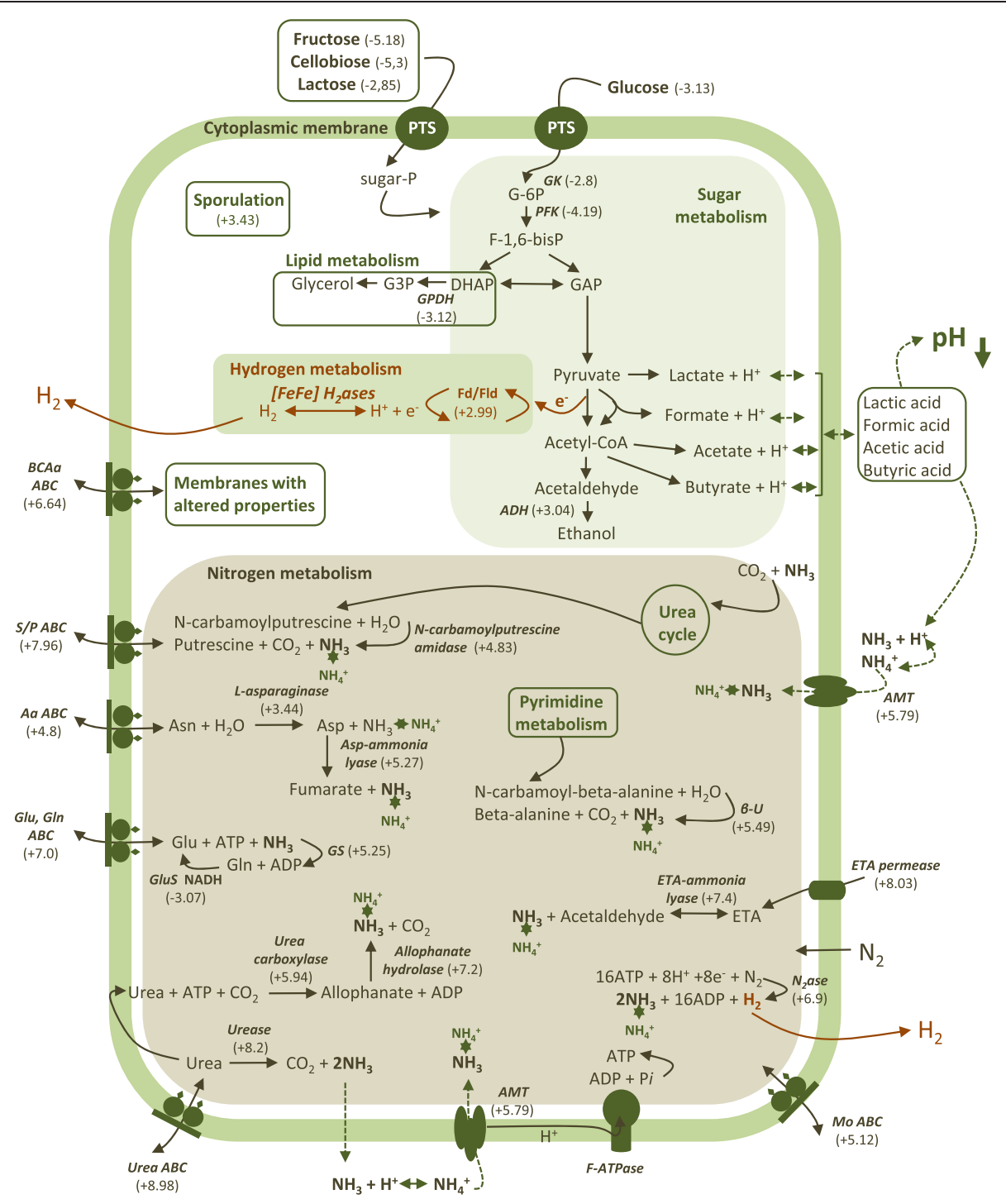

Figure 5 Metabolic pathways for Clostridium butyricum CWBI 1009 affected by decreasing pH during the unregulated-pH glucose fermentation. The numbers are the calculated averages of the individual calculated expression ratios when several subunits encoding the same enzyme were detected to be differentially expressed by RNA-seq. Pathways directly related to $\mathrm{H}_{2}$ production are indicated in red. The dashed lines refer to pathways involved in $\mathrm{pH}$ regulation. $A a A B C$ : amino acid $A B C$ transporter; $A D H$ : alcohol dehydrogenase; $A M T$ : ammonium transporter; $\beta$-U: Beta-ureidopropionase; $B C A a A B C$ : branched-chain amino acid $A B C$ transporter; ETA: ethanolamine permease; Fd/Fld: ferredoxin, flavodoxin; GK: glucokinase; Glu/Gln ABC: glutamate/glutamine ABC transporter; GluS: NADH-glutamate synthase; GS: glutamine synthetase; [FeFe] $\mathrm{H}_{2}$ ase: [FeFe] hydrogenase; MOABC: molybdenum ABC transporter; $N_{2}$ ase: nitrogenase; PFK: 1-phosphofructokinase; $S / P A B C$ : spermidine/putrescine $A B C$ transporter; Urea $A B C$ : urea $A B C$ transporter.

Cytoplasmic pH buffering is one of the strategies employed by many microorganisms to maintain $\mathrm{pH}$ homeostasis, involving the production of various different buffer molecules such as amino acids, ammonia and polyamines, [21]. With declining external $\mathrm{pH}$ (the $\mathrm{pK}$ for ammonia is 9.25), the ammonia produced may buffer the cytoplasm via the $\mathrm{H}^{+}+\mathrm{NH}_{3} \leftrightarrow \mathrm{NH}_{4}^{+}$reaction. Another enzyme for which various subunits were upregulated sixfold to ninefold $\left(\log _{2}\right.$ scale) was urease. It is a nickel-containing enzyme which catalyses the hydrolysis of urea to ammonia and carbamic acid, with the latter spontaneously hydrolysing to carbonic acid and an additional ammonia molecule [22]. Most bacteria use the products of this reaction for anabolic processes, but at low $\mathrm{pH}$ these moieties may be used for cytoplasmic buffering. Additionally, the up-regulation of urea carboxylase and allophanate hydrolase at pH 6.3 may indicate the existence in C. butyricum CWBI 1009 of another pathway for urea breakdown that also leads to the formation of ammonia and carbon dioxide. Moreover, at $\mathrm{pH} 6.3$ several additional pathways that could contribute to cytoplasmic $\mathrm{pH}$ buffering via 
ammonia synthesis (for example, L-asparaginase, ethanolamine ammonia-lyase, beta-ureidopropionase, aspartate ammonia-lyase and N-carbamoylputrescine amidase) were also significantly up-regulated (Figure 5, Additional file 4: Table S6).

\section{Cellular response to decreasing $\mathrm{pH}$ involves differential regulation of $A B C$ transporters and other transport proteins}

Molecular pumps, which are unidirectional efflux systems that actively expel various chemical substances or ions from the cytoplasm to the extracellular space, have been shown to play a role in acid tolerance in yeast [23]. ABC transporters are membrane-bound molecular pumps that utilise ATP hydrolysis energy to translocate a large variety of solutes across cellular membranes. In our study numerous genes related to the various $A B C$ transporters were up-regulated following the progressive drop in $\mathrm{pH}$, that is, $\mathrm{ABC}$ transporters for spermidine, putrescine, arginine, glutamine, branched-chain amino acids, molybdate and other metal ions (Figure 5, Additional file 4: Table S7). Due to their positive charges, polyamines, including spermidine and putrescine, bind to macromolecules such as DNA, RNA and proteins, exerting a protective effect. In bacteria they have been shown to be involved in stress responses, particularly acid tolerance [24]. They are also involved in various different processes, including regulation of gene expression, cell proliferation, cell signaling and membrane stabilisation [25]. Other more frequently transported compounds were the branched-chain amino acids which are involved in the biosynthesis of membranes with altered properties (fluidity). Their increased transport and biosynthesis in C. acetobutylicum in response to butyrate and butanol stresses have been previously described [15].

\section{Expression of sporulation genes is strongly induced by decreasing $\mathrm{pH}$}

During the late exponential growth phase, when the $\mathrm{pH}$ of the medium decreased to 6.3, several genes associated with sporulation were significantly induced, constituting around $5 \%$ of the differentially regulated genes (Additional file 4: Table S9). Furthermore, the RNA polymerase sporulationspecific sigma factor, SigE, that was reported to be responsible for the expression of stage II sporulation-specific genes in Bacillus [26], was also up-regulated by a factor of $3.34\left(\log _{2}\right.$ scale) at $\mathrm{pH}$ 6.3. The initiation of endospore formation is usually accompanied by reduced chemotaxis and motility, and such a down-regulation was observed here for two genes, the methyl-accepting chemotaxis protein (MCP) signalling domain and a putative methyl-accepting chemotaxis protein. In contrast to our observations, the expression of sporulation genes in some solventogenic clostridia, for example,
C. acetobutylicum, has been reported as being largely unaffected by a low $\mathrm{pH}$ [15]. Instead, to prevent the collapse of the transmembrane $\mathrm{pH}$ gradient, some solventogenic bacteria react by solvent production which allows the external $\mathrm{pH}$ to increase. Solventogenic Clostridium beijerinckii NCIMB 8052 was reported to initiate sporulation concurrently with the onset of solventogenesis [14]. Although C. butyricum CWBI 1009 is also capable of producing solvents, mainly ethanol, it does so concomitantly with the production of acids during the exponential growth phase and at a lower concentration (Figure 1G). Therefore, to keep the internal $\mathrm{pH}$ close to the optimum during fermentative growth, C. butyricum CWBI 1009 employs various different mechanisms for proton disposal as described above. Additionally, the bacterium appears to initiate sporulation even during the early stages of its fermentative growth to prevent cell lysis and death due to the re-uptake, via the membrane, of the fatty acids produced. This typically occurs when the $\mathrm{pH}$ decreases below the pKa value (for example, formate pKa 3.77, acetate pKa 4.76, butyrate pKa 4.83) [27].

\section{Proteomic response to decreasing $\mathrm{pH}$}

While mRNAs are mediators of certain biological functions and provide information on transcriptional patterns, most functions are carried out by proteins. Therefore, to gain a better understanding of clostridial hydrogen metabolism, the changes in the relative protein abundance profiles for C. butyricum CWBI 1009 were analysed in response to naturally decreasing $\mathrm{pH}$. For this purpose liquid samples were harvested at $\mathrm{pH} 7.3$ (control sample, Figure 1A) and $\mathrm{pH} 5.2$ (test sample) during the unregulated-pH fermentation. The experiment was successfully carried out on two separate biological replicates (two independent cultures). The protein abundances were analysed by two-dimensional difference in gel electrophoresis (2D-DIGE) (Additional file 1: Figure S3). Overall 2,750 spots exhibiting differences $(>20 \%)$ in the normalised spot-volume ratios were detected; 1,423 of these spots increased and 1,327 decreased in size at $\mathrm{pH} 5.2$ versus $\mathrm{pH}$ 7.3. More than 500 protein spots varied significantly and were subjected to in-gel tryptic digestion, followed by mass spectrometry fingerprinting of the resulting peptides. The experiment was successfully carried out on two separate biological replicates (two independent cultures). A total of 166 proteins (97 unique and 69 redundant) with significant Mascot probability-based scores were identified and categorised according to their metabolic functions (Additional file 5: Table S10 and S11). Overall 16.5\% of the identified proteins were associated with energy metabolism, $10.3 \%$ with protein synthesis, $8.2 \%$ with signal transduction and $7.2 \%$ with amino acid biosynthesis. Though none of the differentially abundant protein spots 
were identified as $[\mathrm{FeFe}]$ hydrogenases or nitrogenase, a differential abundance of these two enzymes between the two $\mathrm{pH}$ conditions cannot be excluded since not all of the statistically differentially abundant proteins were identified after matrix-assisted laser desorption/ionisation time of flight (MALDI-TOF)/TOF analysis.

\section{Central metabolic enzymes and the proteins involved in} fermentative pathways appear more abundant at lower $\mathrm{pH}$ C. butyricum CWBI 1009 utilises the Embden-MeyerhofParnas pathway for the conversion of glucose to phosphoenolopyruvate (PEP, Figure 5). The core metabolic proteins, such as glucose kinase $(+2.52$-fold more abundant at $\mathrm{pH} 5.2)$, phosphofructokinase $1(+2.21)$, phosphopyruvate hydratase $(+2.02)$ and pyruvate kinase $(+1.88)$, that predominantly determine the carbon and electron flow from the carbohydrate substrate to the end-products were more abundant at $\mathrm{pH} 5.2$ compared to $\mathrm{pH} 7.3$ (Additional file 5: Table S11). Electrons derived from the main glycolytic nodes, namely pyruvate-ferredoxin oxidoreductase (PFOR) and to a lesser extent NADHferredoxin oxidoreductase (NFOR), are passed on by electron acceptors to the hydrogenases, thereby enabling the reversible reduction of the protons accumulated during the fermentation process to molecular hydrogen [28]. Also, the reducing equivalents necessary for $\mathrm{N}_{2}$ fixation are mainly obtained by the nitrogenase via reduced ferredoxin, which can be generated by the action of PFOR [29]. In line with these reports, seven redundant proteins identified as PFOR were all more abundant at pH 5.2 (on average +2.37 ). By contrast, the relative abundance of type I glyceraldehyde-3-phosphate dehydrogenase, a tetrameric NAD-binding protein, was decreased at lower $\mathrm{pH}$ (on average -1.74), suggesting a limited flow of electrons via the NFOR node and towards the putative bifurcating [FeFe] hydrogenase (Hyd A8) [12,30]. Electron transferring flavoprotein $(+1.73)$ and flavodoxin $(+1.69)$ were also more abundant at lower $\mathrm{pH}$, which was consistent with the RNA-seq data for the low $\mathrm{pH}$ condition.

Among the other proteins that were more abundant at acidic pH, a cysteine desulphurase NifS $(+4.89)$ and an iron-sulphur cluster-binding protein $(+1.92)$ were identified (Additional file 5: Table S11). The function of the former is to mobilise sulphur atoms for the biosynthesis of iron-sulphur (FeS) clusters. Both proteins are involved in the maturation process of various FeS proteins, such as hydrogenases and nitrogenases [31].

As regards the nitrogen metabolism, the 2D-DIGE analysis did not confirm the differential abundance of the nitrogenase, but did however show that glutamine synthetase was more abundant (by an average factor of +1.72 ) at lower $\mathrm{pH}$. The mRNA level for the corresponding gene was also higher at the low-pH stage of the fermentation (Additional file 2: Table S4 and
Additional file 3: Table S5). In free-living diazotrophs fixed $\mathrm{N}_{2}$ is assimilated by the organism in the form of ammonium to produce glutamine and glutamate. This occurs via the glutamine synthetase/glutamate synthase pathway in accordance with the equation: glutamate + $\mathrm{ATP}+\mathrm{NH}_{3} \leftrightarrow$ glutamine $+\mathrm{ADP}+\mathrm{Pi}[32]$. Therefore, the ability to synthesise glutamate and glutamine is essential to the cellular metabolism, since they are involved in the incorporation of inorganic nitrogen into cell material; that is, the synthesis of new proteins $[32,33]$. Further ammonia incorporation occurs through the action of NAD(P)-specific glutamate dehydrogenase, and this protein also was found to be 1.81-fold more abundant at lower $\mathrm{pH}$. Moreover, amino acids such as glutamate have been described as known osmoprotectants and have been shown to play a role in acid tolerance in, for example, C. acetobutylicum [15].

The HPLC analyses for metabolites indicated that, in addition to formate, acetate and butyrate were the main fermentation end-products obtained when C. butyricum CWBI 1009 was cultured under unregulated-pH conditions (Figure 1G). Therefore, it was not surprising that acetate and butyrate kinases were respectively 1.49 - and 1.68-fold more abundant at the lower $\mathrm{pH}$ compared to $\mathrm{pH}$ 7.3. Additionally, acetyl-CoA acetyltransferase (thiolase), which catalyses the first steps of the butyrate synthesis pathway [32], was also more abundant at the lower $\mathrm{pH}(+1.51)$. Of the other core fermentative enzymes, type II acetaldehyde/alcohol dehydrogenase was also more abundant, suggesting that increased alcohol production was associated with decreasing $\mathrm{pH}$.

\section{$\mathrm{H}_{2}$ production from glucose at fixed $\mathrm{pH} 5.2$ is likely to be hydrogenase- mediated}

Maintaining the C. butyricum CWBI 1009 culture at fixed $\mathrm{pH} 5.2$ (Figure 1F) led to a $50 \%$ increase in cumulative $\mathrm{H}_{2}$ production (in comparison to the unregulated-pH culture; Figure 1D). Furthermore, bacterial fermentations at fixed acidic $\mathrm{pH}$ are commonly used for efficient $\mathrm{H}_{2}$ production. This is why glucose fermentations were also performed at two different fixed $\mathrm{pH}$ values, namely $\mathrm{pH} 7.3$ (control fermentation with best growth) and $\mathrm{pH} 5.2$ (test fermentation with best $\mathrm{H}_{2}$ production). In addition to the description of the fermentative profiles characteristic for the two fixed $\mathrm{pH}$ values, RT-qPCR was used to study the gene expression levels for the [FeFe] hydrogenases and the nitrogenase.

At $\mathrm{pH} 7.3$ no differential gene expression occurred throughout the fermentation (Figure 6A), as was expected given the barely detectable $\mathrm{H}_{2}$ production (Figure 1E). Surprisingly, at fixed $\mathrm{pH} 5.2$, although the $\mathrm{H}_{2}$ production rate constantly increased during the fermentation, no change in the gene expression pattern was detected between the early and the late exponential stages of 


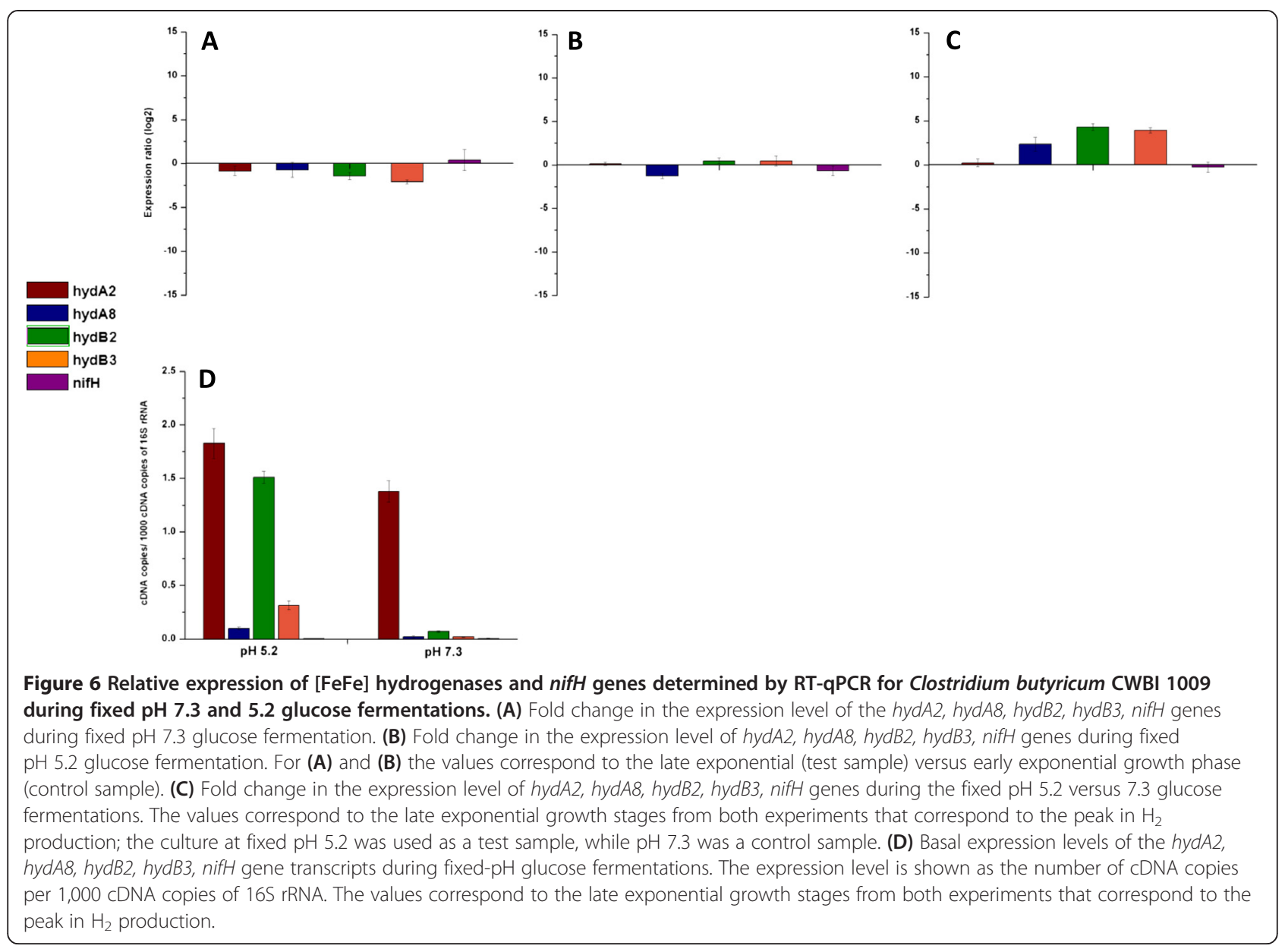

fermentation, neither for the nitrogenase nor for the [FeFe] hydrogenases (Figure 6B). This apparent lack of change in the temporal gene expression profile could be due to the fact that the bacterial pre-culture, used to inoculate the reactor, was pre-incubated at $\mathrm{pH} 5.2$ as well. Therefore, the lower $\mathrm{H}_{2}$ production observed at the beginning of the fixed $\mathrm{pH} 5.2$ fermentation (Figure 1F) was more likely attributable to low cell density rather than any differential [FeFe] hydrogenase gene expression. Since the $\mathrm{pH}$ was kept constant during the whole fermentation, the [FeFe] hydrogenases could not have been activated by a change in $\mathrm{pH}$ [34].

A direct comparison of the gene expression profiles for the same growth stage at the two different fixed $\mathrm{pHs}$ showed that the [FeFe] hydrogenase gene transcripts were indeed differentially abundant. During the late exponential growth phases (10 h incubation, Figure $1 \mathrm{~B}$ and $\mathrm{C}$ ), when the $\mathrm{H}_{2}$ production rate reached the maximum for both cultures (Figure $1 \mathrm{E}$ and $\mathrm{F}$ ), the monomeric hydrogenase gene hydA2 showed similar expression levels at fixed pH 5.2 and at fixed pH 7.3 (Figure 6C). Surprisingly, its basal expression at pH 5.2 was between 1.2- and 6 -fold higher than that for $h y d B 2$ and for hydB3 respectively, and as much as 18 times higher than that for the hydA8 gene (Figure 6D). Hydrogenase A8 is a putative trimeric hydrogenase that requires both reduced ferredoxin and $\mathrm{NADH}$ to efficiently catalyse $\mathrm{H}_{2}$ production [30]. Its relatively low expression level compared to the other [FeFe] hydrogenases may suggest that there was less electron flow through the NFOR node than through the PFOR node (in line with the 2D-DIGE data). During the same late exponential growth phase the remaining two monomeric hydrogenase gene transcripts (hydB2 and hydB3) were respectively 4.28 - and 3.9 -fold more abundant $(P<0.05$, $\log _{2}$ scale) at fixed $\mathrm{pH} 5.2$ compared to fixed $\mathrm{pH}$ 7.3.

The data obtained suggest two main conclusions. Firstly, based on the cDNA copy numbers, hydA2 is the most abundant hydrogenase and seems to be insignificantly regulated under the two different fixed $\mathrm{pH}$ conditions. Secondly, both hydB2 and hydB3 are very strongly up-regulated at fixed $\mathrm{pH} 5.2$ versus fixed $\mathrm{pH} 7.3$; however, the basal expression level of hydB2 at fixed $\mathrm{pH} 5.2$ was around five times higher than that for hydB3 (Figure 6D). Of particular interest also is the observation that during the unregulated-pH fermentation the basal expression levels of the four [FeFe] hydrogenase coding 
genes were lower than their expression levels at fixed $\mathrm{pH} 5.2$ (10 h incubation, late exponential growth phase, Figure 4B and Figure 6D). For the two fixed-pH fermentations the expression level of the nifH gene was similar (Figure 6C), and was significantly lower than during the unregulated-pH glucose fermentation (Figure 4B). A Western blot analysis carried out on samples corresponding to the different fermentation stages for both fixed-pH cultures gave no positive signal for the NifH subunit (data not shown). This observation suggests that in contrast to the unregulated-pH glucose fermentation, where a strong up-regulation of nitrogenase genes was observed, $\mathrm{H}_{2}$ production at fixed $\mathrm{pH} 5.2$ may be essentially hydrogenase-mediated.

To better understand the phenomenon of possibly differential nitrogenase- and hydrogenase-mediated $\mathrm{H}_{2}$ production in clostridia under different $\mathrm{pH}$ conditions, further investigation is required. Moreover, the genetic elements for the transcriptional control of the nif operon have not yet been well defined in clostridia [27]. Nevertheless, it is tempting to speculate about the significance of the differential carbon metabolisms (Figure $1 \mathrm{G}$ and I) observed for fermentation under unregulated- $\mathrm{pH}$ compared with fermentation under fixed $\mathrm{pH} 5.2$ condition. This may be an indication of metabolic adaptations affecting the $\mathrm{H}_{2}$-producing enzymes, thereby leading to distinct $\mathrm{H}_{2}$ production profiles (Figure $1 \mathrm{D}$ and $\mathrm{F}$ ). Interestingly, it has recently been shown that the nitrogenasemediated $\mathrm{H}_{2}$ evolution in a photoheterotrophic bacterium Rhodobacter sphaeroides was enhanced by ethanol $[35,36]$. Oh et al. [36] reported a $60 \%$ increase in $\mathrm{H}_{2}$ production in the presence of ethanol in the ammonium-containing medium. Moreover, the authors showed that the increased nitrogenase activity was regulated at the level of nifHDK transcription and that ethanol was not used as a carbon source by the bacterium. Though the study discusses another type of bacterium, it can be compared with the unregulated-pH fermentation in our study, where both an increase in the production of ethanol and transcription of nif genes were detected and were concurrent with a higher $\mathrm{H}_{2}$ production. In contrast, during fixed $\mathrm{pH} 5.2$ glucose fermentation, where no ethanol production was observed, the expression level of nifH was significantly lower as well.

Nevertheless, there are still unresolved questions concerning the metabolic fluxes and regulations in clostridia that need to be studied before a more grounded hypothesis can be made, especially as our study is the first to suggest, based on transcriptional analysis, a putative involvement of nitrogenase to the overall $\mathrm{H}_{2}$ production in this bacterial genus.

\section{Conclusions}

This paper presents a biomolecular overview of the changes occurring when the metabolism of C. butyricum CWBI
1009 shifts to $\mathrm{H}_{2}$ production. The results show that the cellular metabolism for all the tested metabolites varied under all conditions and was $\mathrm{pH}$ dependent. The primary soluble metabolites were formate, acetate and butyrate, followed by ethanol and lactate. The highest $\mathrm{H}_{2}$ yield (1.78 $\pm 0.11 \mathrm{~mol} \mathrm{H}_{2} / \mathrm{mol}$ glucose) was in accordance with previous studies with the same strain $[9,10]$. Further investigations into the genomic/proteomic changes associated with naturally decreasing $\mathrm{pH}$ and with $\mathrm{H}_{2}$ production indicated the differential regulation of numerous genes/ proteins; some were known to be directly associated with $\mathrm{H}_{2}$ production (for example, hydrogenases and pyruvate-ferredoxin oxidoreductase). However the upregulation of others, such as those involved in $\mathrm{N}_{2}$ assimilation, were more surprising, since $\mathrm{H}_{2}$ production in clostridia has never before been described as nitrogenase-mediated.

As the transcription levels of the [FeFe] hydrogenases and the nitrogenase coding genes varied significantly between different fermentations, transcriptional analyses indicated the need for further biochemical characterisation of the $\mathrm{H}_{2}$-producing enzymes, especially for the [FeFe] hydrogenases HydA8, B2 and B3, which have not yet been studied [6]. Additionally, the identification of multiple hypothetical genes/proteins (Additional file 2: Table S4) that were differentially regulated suggests that other unknown mechanisms may be governing $\mathrm{H}_{2}$ production in clostridia. This could therefore be fertile ground for $\mathrm{fu}$ ture studies.

This work contributes to the field of dark fermentative hydrogen production by providing a multidisciplinary approach for the investigation of the processes involved in the molecular $\mathrm{H}_{2}$ metabolism of clostridia, which could in time lay the groundwork for further optimisation based on genetic engineering techniques [3].

\section{Methods}

\section{Microorganism and growth conditions}

The strain Clostridium butyricum CWBI 1009 was isolated from an anaerobic sludge and cultivated in a modified MDT medium as previously described [9]. The modified MDT medium contained, per litre of deionised water: glucose monohydrate $(10 \mathrm{~g})$, casein pepton $(5 \mathrm{~g})$, yeast extract $(0.5 \mathrm{~g}), \mathrm{Na}_{2} \mathrm{HPO}_{4}(5.1 \mathrm{~g}), \mathrm{KH}_{2} \mathrm{PO}_{4}(1.2 \mathrm{~g})$, $\mathrm{MgSO}_{4} \cdot 7 \mathrm{H}_{2} \mathrm{O}(0.5 \mathrm{~g})$, and cystein hydrochloride $(0.5 \mathrm{~g})$. The PCA (Plate Count Agar) medium, used to verify the absence of aerobic and facultative aerobic contaminants, contained per litre of deionised water: glucose monohydrate $(1 \mathrm{~g})$, casein peptone $(5 \mathrm{~g})$, yeast extract $(2.5 \mathrm{~g})$, and agar $(15 \mathrm{~g})$. All the chemicals used were of analytical or extra pure quality and were supplied by Merck, UCB and Sigma. Casein peptone and yeast extract were supplied by Organotechnie (La Courneuve, France). 


\section{Reactor setup and experimental procedure}

Fermentations were carried out in a 20-L laboratoryscale bioreactor (Biolafitte Niort, F) consisting of a double envelope and a stainless steel lid equipped with a butyl septum, $0.20-\mu \mathrm{m}$ gas filters (Midisart, Sartorius) and tubing (for gas inlet, gas outlet and medium removal). Prior to inoculation the bioreactor and the medium were sterilised at $120^{\circ} \mathrm{C}$ for $20 \mathrm{~min}$. Glucose and cystein were autoclaved separately in 2.5 -L flasks to prevent Maillard reactions, and were then added sterilely to the tank before being cooled and purged with $\mathrm{N}_{2}$ or Ar. After inoculation with $1.7 \mathrm{~L}$ of pre-culture (obtained in 2-L hermetic bottles incubated for 24 hours at $30^{\circ} \mathrm{C}$ ), the bioreactor had a final working volume of $17 \mathrm{~L}$. Finally the $\mathrm{pH}$ was adjusted to either 7.3 or $5.2 \pm 0.1$ via automatic addition of sterile $1.5 \mathrm{~N} \mathrm{KOH}$ combined with a Mettler Toledo probe (465-35-SC-P-K9/320) and needles inserted through the septum. For the unregulated$\mathrm{pH}$ fermentation, after setting the initial $\mathrm{pH}$ value at $7.6 \pm 0.1$, the controller for base addition was turned off. Three biological replicates corresponding to each $\mathrm{pH}$ condition (unregulated $\mathrm{pH}$, fixed $\mathrm{pH} 7.3$ and fixed $\mathrm{pH}$ 5.2) were prepared and monitored for 25 hours. Throughout the fermentation, the bioreactor was maintained at $30^{\circ} \mathrm{C}$ and stirred at $100 \mathrm{rpm}$.

\section{Biogas and metabolite monitoring}

The biogas flow rate was measured by a MilliGasCounter1 PMMA Ritter flow meter connected to a computer (Rigamo V1.30-K1 software, acquisition every 30 seconds). The biogas production was also regularly checked with a second drum-type flow meter (Ritter TG01) connected in series. The proportion of hydrogen gas was determined using a gas chromatograph (GC) (Hewlett-Packard 5890 Series II) fitted with a thermal conductivity detector (TCD) and a $30 \mathrm{~m} \times 0.32 \mathrm{~mm}$ GasPro GSC capillary column (Altech) in series with a $20 \mathrm{~m} \times 0.25 \mathrm{~mm}$ CarboPLOT P7 column (Chrompak). The temperatures of the injections, the TCD chambers and the oven were maintained at $90^{\circ} \mathrm{C}, 110^{\circ} \mathrm{C}$ and $55^{\circ} \mathrm{C}$, respectively. Nitrogen was used as the carrier gas in the column at a flow rate of 20 $\mathrm{ml} \mathrm{min}{ }^{-1}$. The harvested liquid samples were centrifuged at $13,000 \mathrm{~g}$ for $1 \mathrm{~min}$, and the supernatant was filtered through a $0.2-\mu \mathrm{m}$ cellulose acetate membrane (Minisart, Sartorius) before HPLC analysis for glucose, ethanol, lactate, acetate, formate and butyrate. HPLC was carried out using an Agilent 1110 series chromatograph (HP Chemstation software) with a Supelcogel C-610H column preceded by a Supelguard $\mathrm{H}$ pre-column (oven temperature $40^{\circ} \mathrm{C}$ ). $0.1 \% \mathrm{H}_{3} \mathrm{PO}_{4}$ (in Milli-Q water) was used for the isocratic mobile phase (flow rate of $0.5 \mathrm{ml} \mathrm{min}^{-1}$ ) using a differential refraction index detector (RID, heated at $35^{\circ} \mathrm{C}$ ). The method lasted for $35 \mathrm{~min}$ at a maximum pressure of 60 bar. The data for the glucose and metabolite concentrations were used to calculate the mass balance (MB) of the glucose conversion as described previously [37].

\section{RNA extraction}

For RNA extraction, the RiboPure ${ }^{\text {tx }}$-Bacteria (Ambion) extraction kit was used. The cells in a 2-ml suspension were harvested by centrifugation $(16,000 \mathrm{~g}$ for $1 \mathrm{~min})$, frozen in liquid nitrogen and stored at $-80^{\circ} \mathrm{C}$. The RNA extraction was performed according to the instruction manual. The total RNA was eluted by the addition of 50 $\mu \mathrm{l}$ of the preheated elution solution. Before reverse transcription, any contaminating DNA was removed by a double treatment with TURBO DNase (TURBO DNAfree $^{\mathrm{m}}$, Ambion), according to the instruction manual. In each step, the reaction mixture was incubated at $37^{\circ} \mathrm{C}$ for $30 \mathrm{~min}$. After the second incubation step, the DNase was inactivated by the addition of the DNase inactivation reagent at a concentration of $20 \%$ of the volume of the treated RNA. The mix was then incubated for $2 \mathrm{~min}$ at room temperature and subsequently centrifuged for 1 min at $10,000 \mathrm{~g}$ to pellet the inactivation reagent. The absence of the genomic DNA contamination was confirmed by qPCR directly using $5 \mathrm{ng}$ of total RNA. Total RNA concentrations were determined with a NanoVue spectrophotometer (GE Healthcare), and the RNA integrity was checked on a formaldehyde-agarose gel. Before RNA-seq, the RNA quality was checked on an automated electrophoresis system (Experion, BioRad). The RNA was stored at $-80^{\circ} \mathrm{C}$ before analysis. First-strand cDNA was synthesised with the Reverse Transcription System (Promega, Madison, WI, USA) according to the manufacturer instructions. The total volume of the reaction mixture was $20 \mu \mathrm{l}$ and contained $500 \mathrm{ng}$ of the total RNA and 500 ng of the control mouse RNA (Quantum RNA $^{\mathrm{Tm}}$ ß-actin Internal Standards, Ambion). Control mouse RNA was used as an external standard. The reaction was primed with the random primers supplied with the kit. Obtained cDNAs were diluted in diethylpyrocarbonate (DEPC)-treated water to a final concentration of 5 ng initial total RNA/ $\mu$ l.

\section{mRNA sample preparation and RNA-seq analysis}

$10 \mu \mathrm{g}$ of extracted total RNA was treated with the MICROBExpress ${ }^{\text {Tn }}$ Kit (Ambion) to enrich for mRNA, by removing the $16 \mathrm{~S}$ and $23 \mathrm{~S}$ rRNA. Paired-end libraries were prepared according to the TruSeq ${ }^{\text {rx }}$ RNA Sample Preparation Guide (Illumina). The library preparation and Illumina RNA sequencing was performed by the GIGA transcriptomics platform (Liège, Belgium). Obtained reads were aligned using the BWA software using default parameters [38]. Raw counts per gene were calculated based on the genome annotation of Clostridium butyricum CWBI 1009. Reads were allowed to map 50 bp upstream of the start codon or $50 \mathrm{bp}$ downstream of 
the stop codon. Reads mapping to ribosomal or transporter RNA were removed from the raw counts data to prevent bias in detecting differential expression. Differential expression was calculated using the edgeR package (version 3.2.4) [39] in BioConductor (release 2.12, R version 2.15.0), resulting for each gene in a fold change and a corresponding $P$-value corrected for multiple testing. Genes with a 2-fold $\left(\log _{2}\right)$ up or down-regulation and a corrected $P$-value lower than 0.05 were assigned as being differentially expressed.

\section{Clostridium butyricum CWBI 1009 genome sequencing}

The Clostridium butyricum CWBI 1009 genome was sequenced by BaseClear (Leiden, The Netherlands) using the pair-end sequencing on the Illumina Hiseq 2000. Genome assembly was performed using Velvet version 1.2.10 [40], using a hash length of 29 , a minimum contig length of 500 and a minimal coverage of 20. The Whole Genome Shotgun project was deposited at [DDBJ/ EMBL/GenBank:ASPQ00000000]. The accession version described in this paper is version ASPQ01000000 (Additional file 1: Table S12).

\section{RT-qPCR}

Species-specific primers and probes are listed in Table 1. $ß$-actin-specific primers were taken from the kit (QuantumRNA $^{\text {mo }} \beta$-actin Internal Standards, Ambion). The quantitative PCR amplifications were carried out with a Mini Opticon (BioRad). The DNA template used for a standard curve was prepared as previously described [41]. For the gene expression analysis, $1 \mu \mathrm{l}$ of cDNA was used. The total volume of the PCR mix was $25 \mu \mathrm{l}$. Each reaction consisted of $1 \times$ PCR mix (ABsolute ${ }^{\mathrm{Tx}}$ Blue QPCR SYBR ${ }^{\circ}$ Green Fluorescein Mix or ABsolute ${ }^{\text {tw }}$ Blue QPCR mix, Thermo Scientific), each primer and/or hydrolysis probe (HPLC cleaned, Biomers, Germany) at a final concentration of $150 \mathrm{nM}$. Each sample was analysed in triplicate. A 'no template' control was included in each run. The specificities of the primers were verified at the end of each qPCR reaction by performing the melting curve analysis (for a SYBR Green-based quantification). The standard curve preparation and the cycling conditions for SYBR Green chemistry were as previously described [41]. For the probe-based chemistry, the initial denaturation of $15 \mathrm{~min}$ was followed by 40 cycles of denaturation at $95^{\circ} \mathrm{C}$ for $15 \mathrm{~s}$ and primer annealing/amplification step at $60^{\circ} \mathrm{C}$ for $30 \mathrm{~s}$. The reaction efficiency was calculated as factor specific [42] according to the equation: $\mathrm{E}=10^{-1 / \text { slope }}$. For gene expression analysis, the relative expression levels were calculated with a Relative Expression Software Tool 2009, REST@ [43]. To estimate the up- and down-regulation of analysed genes, the obtained Cqs were compared to those of the reference genes and an external standard control gene. Two internal reference genes, 16S rRNA and $r e c A$, and one external RNA control gene ( $\beta$-actin) were used. An external mouse RNA was added to the sample RNA before the cDNA synthesis to correct for intrinsic and technical variations introduced throughout the experimental process [44]. The stability of the chosen reference genes and the integrity of each RNA sample were evaluated using the BestKeeper Excel-based tool [45] (data not shown).

Table 1 List of C. butyricum CWBI 1009-specific primers and probes used in this study

\begin{tabular}{|c|c|c|c|c|}
\hline Target gene & Primer/probe & Sequence $5^{\prime} \rightarrow 3^{\prime}$ & Length (bp) & Ref. \\
\hline \multirow[t]{2}{*}{ recA } & RecA-ButF & AAGCATTAGTGCGTTCTGGAG & 97 & {$[41]$} \\
\hline & RecA-ButR & GAATCTCCCATTTCCCCTTC & & \\
\hline \multirow[t]{2}{*}{ hydA2 } & ButA2F & ATAGTTGCAATGGCTCCTGC & 250 & This study \\
\hline & ButA2R & TTTCTGCTTGCCTAACCCAT & & \\
\hline \multirow[t]{2}{*}{ hydA8 } & ButA8F & TCTTTGAGTTACAGGGGGA & 188 & This study \\
\hline & ButA8R & TTCAGCATTTGCAAGACCAC & & \\
\hline \multirow[t]{2}{*}{ hydB2 } & ButB2F & TGGTGGTGTATCAACTGCTG & 168 & This study \\
\hline & ButB2R & TTGCATCCCATTCCTTCAAT & & \\
\hline \multirow[t]{2}{*}{ hydB3 } & ButB3F & CAATGGTTGCTACAGGCAGA & 168 & This study \\
\hline & ButB3R & CAAAAGCATCGAATAACGCA & & \\
\hline \multirow[t]{3}{*}{ 16S rRNA } & 16SButF & CCTGCCTCATAGAGGGGAAT & 143 & This study \\
\hline & 16SButR & GAGCCGTTACCTCACCAACT & & \\
\hline & HP16SBut ${ }^{a}$ & CCGCATAAGATTGTAGTACCGCATGGTACA & & \\
\hline \multirow[t]{2}{*}{ nifH } & NifHButF & CATCAGCATTGGCTGAGATG & 206 & This study \\
\hline & NifHButR & TGGTTCTGGTCCTCCTGATT & & \\
\hline
\end{tabular}

a HP: hydrolysis probe. 


\section{Western blot analysis}

Whole cell protein extracts were prepared by sonicating the bacteria in TpW buffer (100 mM TRIS, $150 \mathrm{mM}$ $\mathrm{NaCl}, 1 \mathrm{mM}$ EDTA). The cell lysates were centrifuged $(16,000 \mathrm{~g}$ for $20 \mathrm{~min})$ and protein concentrations in lysates were estimated using the Bradford assay, performed according to the manufacturer protocol (Fermentas). Western blot analysis was performed using a hen polyclonal affinity purified IgY raised against the $\mathrm{NifH}$ subunit of nitrogenase (Agrisera, Sweden). As a positive control, cell lysate of Anabaena variabilis was used. $5 \mu \mathrm{g}$ of the whole protein extracts were directly subjected to $10 \%$ SDSPAGE and then blotted onto Immobilon-P membrane (Millipore). Membranes were blocked for $1 \mathrm{~h}$ with TBST (20 mM Tris, $140 \mathrm{mM} \mathrm{NaCl}, 0.1 \%$ Tween, $\mathrm{pH}$ 7.6) containing 3\% BSA, and then incubated with 1:2,000 diluted antibody in TBST, overnight at $4^{\circ} \mathrm{C}$. As secondary antibody, a 1:10,000 dilution of rabbit anti-chicken IgG coupled to alkaline phosphatase (Sigma) was used. Reactive protein bands were detected using NBF/BdP reagents (Sigma).

\section{Sample preparation for 2D-DIGE}

Freshly harvested cells were resuspended in a denaturation buffer (7 $\mathrm{M}$ urea, $2 \mathrm{M}$ thiourea, 2\% ASB-14, 20 mM DTT, Complete EDTA free [Roche], $1 \mathrm{mM}$ EDTA $\mathrm{pH} 8.5,50 \mathrm{mM}$ Tris- $\mathrm{HCl} \mathrm{pH} \mathrm{7.5)} \mathrm{and} \mathrm{intensively} \mathrm{vor-}$ texed for $30 \mathrm{~min}$ at room temperature. Subsequently, the suspensions were briefly sonicated and centrifuged at $10,000 \mathrm{~g}$ for $10 \mathrm{~min}$ to remove any insoluble material. In order to discard the remaining salts, fatty acids and nucleic acids, the protein extracts were precipitated three times and cleaned twice with a 2D-clean up Kit (GE Healthcare). Protein pellets were then resuspended in a DIGE labelling buffer (7 $\mathrm{M}$ urea, $2 \mathrm{M}$ thiourea, 2\% ASB14, EDTA free anti-protease cocktail [Roche], $0.5 \mathrm{mM}$ EDTA $50 \mathrm{mM}$ TRIS adjusted at $\mathrm{pH}$ 8.5). The protein concentration was estimated with an RC/DC protein assay kit (BioRad Laboratories), and was adjusted to a value between 5 and $10 \mathrm{mg} / \mathrm{ml}$ for optimal CyDye labelling. Each sample (containing $25 \mu \mathrm{g}$ of protein) was labelled with $0.2 \mathrm{nmol}$ of either Cy3 or Cy5 (minimal labelling). At the same time, an internal standard consisting of equimolar amounts of the two samples was labelled with Cy2 (GE Healthcare). The labelling reaction was stopped after 30 min by adding $5 \mathrm{nM}$ of lysine. The Cy2, Cy3- and Cy5labelled proteins were pooled together prior to isoelectrofocussing with the IPGphor3 IEF System (GE Healthcare). Pooled samples were reduced by adding $20 \mathrm{mM}$ DTT, resuspended in a Drystrip rehydration buffer (7 M urea, $2 \mathrm{M}$ thiourea, 2\% ASB-14 w/v, 0.6\% IPG Buffer [GE Healthcare] $\mathrm{v} / \mathrm{v}$ ), and then supplemented with Destreak solution (GE Healthcare), to provide a final volume of $450 \mu \mathrm{l}$ which was spread on a 24-cm regular strip holder. The 3-11 NL IPG Drystrips (GE Healthcare) were passively rehydrated in the strip holder for $10 \mathrm{~h}$ at $20^{\circ} \mathrm{C}$ prior to running the IEF under the following conditions: $50 \mathrm{~V}$ for $2 \mathrm{~h}$ (step), $200 \mathrm{~V}$ for $200 \mathrm{Vh}$ (step), $500 \mathrm{~V}$ for $150 \mathrm{Vh}$ (gradient), 500 $\mathrm{V}$ for $500 \mathrm{Vh}$ (step), 1,000 V for $500 \mathrm{Vh}$ (gradient), 8,000 $\mathrm{V}$ for $13,500 \mathrm{Vh}$ (gradient), $8,000 \mathrm{~V}$ for $8,0000 \mathrm{Vh}$ (step) and $500 \mathrm{~V}$ for $10 \mathrm{~h}$ (step); with a maximum current setting fixed at $50 \mu \mathrm{A}$ [46]. After the first electrophoretic migration (first dimension), the strips were reduced in an equilibration buffer (50\% glycerol v/v, 4\% SDS w/v, $6 \mathrm{M}$ urea, $50 \mathrm{mM}$ Tris- $\mathrm{HCl}$ adjusted to $\mathrm{pH} 8.8$ ) and incubated with $300 \mathrm{mM}$ DTT for $15 \mathrm{~min}$. The strips were then alkylated for $15 \mathrm{~min}$ in the same equilibration solution with DTT replaced by $350 \mathrm{mM}$ of iodoacetamide. After equilibration, the strips were put on top of a $12.5 \%$ acrylamide gel in a Laemmli SDS electrophoresis buffer (25 mM Tris, $192 \mathrm{mM}$ glycine, 1\% SDS w/v). Electrophoresis was carried out overnight at $1 \mathrm{~W} / g e l$. Following migration, the gels were scanned (Typhoon 9400, GE Healthcare) at a resolution of $100 \mu \mathrm{m}$ for the excitation wavelengths corresponding to each CyDye. The scanner generated 18 gel images for each biological replicate ( 9 images for the comparison between the two $\mathrm{pH}$ values and 6 images for the internal standard) which were analysed with the DeCyder V7.0 software (GE Healthcare). The co-detection of the three CyDyelabeled forms for each spot was done using the Differential In-gel Analysis (DIA) module. Statistical analysis was carried out in the Biological Variation Analysis (BVA) module after inter-gel matching. Protein spots that resulted in a statistically significant Student's $t$-test value $(P<0.05, \mathrm{n}=6)$ were considered as being differentially abundant at pH 5.2 compared to $\mathrm{pH}$ 7.3.

\section{In-gel digestion and mass spectrometry}

Protein identification was performed using preparative gels $(150 \mu \mathrm{g}$ of loaded material) prepared under the same experimental conditions, but with only one CyDye to label the protein sample (Cy5). In addition, the gel plates were treated with a Bind-silane solution for spot picking. The resulting scanned gels were matched with the BVA module. Matched spots presenting a statistical difference were detected using the Ettan Dalt Spot Picker (GE Healthcare). Subsequently, the proteins in the gel pieces were washed (three times with Milli-Q water and $100 \% \mathrm{ACN}$ and three times with $25 \mathrm{mM} \mathrm{NH}_{4} \mathrm{HCO}_{3}$ and $100 \% \mathrm{ACN})$ to remove excess detergent and buffer. After a final dehydration step in ACN, the gel pieces were rehydrated and treated with $2 \mu \mathrm{l}$ of a $5 \mathrm{ng} / \mu \mathrm{l}$ trypsin proteomic grade solution (Roche) for $2 \mathrm{~h}$ at $4^{\circ} \mathrm{C}$, to ensure sufficient diffusion in the gel. The temperature was then raised to $37^{\circ} \mathrm{C}$ for an overnight digestion. After tryptic digestion, the resulting peptides were extracted from the gel pieces by adding $5 \mu \mathrm{l}$ of a $1 \%$ trifluoroacetic acid (TFA) v/v, $30 \% \mathrm{ACN} \mathrm{v/v} \mathrm{solution,} \mathrm{and} \mathrm{vortexing} \mathrm{for} 30 \mathrm{~min} .1 \mu \mathrm{l}$ of 
the resulting extract was dropped on a 384-600 MTP Anchorship MALDI target plate (Bruker Daltonic), previously spotted with a 3\% w/v HCCA matrix (Sigma) dissolved in acetone. Each drop was washed 3 times with a $10 \mathrm{mM}\left(\mathrm{NH}_{4}\right)_{2}\left(\mathrm{HPO}_{4}\right)$ solution. Protein identification was carried out with MALDI-TOF/TOF instrumentation (Ultraflex II, Bruker Daltonic) in MS and MS/MS modes and the Mascot search engine was configured with a maximal mass error rate at $100 \mathrm{ppm}$ [47]. Protein identification was performed with the Biotools software (Bruker) using the Mascot search engine on the Clostridium butyricum 5521 protein database (Additional file 5: Table S10).

\section{Additional files}

Additional file 1: Figure S1. Double-log scatter of sequence reads and the coefficient of determination $\left(R^{2}\right)$ for the biological replicates of the RNA-seq reads mapped to the genome of Clostridium butyricum CWBI 1009. Figure S2. Correlation of RNA-seq data with RT-qPCR for Clostridium butyricum CWBI 1009 cultivated in a 20L batch bioreactor with glucose (10 g/L) under unregulated-pH conditions. Figure S3. 2D-gel pattern of the Clostridium butyricum CWBI 1009 proteome. Table S1. Bioreactor performance of Clostridium butyricum CWBI 1009 cultivated in a $20 \mathrm{~L}$ batch bioreactor with glucose $(10 \mathrm{~g} / \mathrm{L})$ under unregulated-pH conditions. Table S2. Bioreactor performance of Clostridium butyricum CWBI 1009 cultivated in a 20L batch bioreactor with glucose $(5 \mathrm{~g} / \mathrm{L})$ at fixed pH 7.3 and 5.2. Table S3. Summary of Clostridium butyricum CWBI 1009 RNA-seq data results. Table S12. Summary of Clostridium butyricum CWBI 1009 genome information.

Additional file 2: RNA-seq data. Table S4. List of the most highly expressed genes at $\mathrm{pH} 6.3$ (column indicated in bold type) during glucose fermentation under unregulated-pH conditions.

Additional file 3: RNA-seq data. Table S5. Differentially regulated genes in C. butyricum CWBI 1009 in response to the decline in $\mathrm{pH}$ (unregulated-pH glucose fermentation) as analysed by RNA-seq.

Additional file 4: RNA-seq data. Table S6. Acid stress response: alkalisation of the internal/external environment. Genes and pathways regulated at acidic $\mathrm{pH} 6.3$ versus 7.3 during glucose fermentation under unregulated-pH conditions (RNA-seq data). Table S7. Acid stress response: cellular transport. Genes differentially regulated at acidic pH 6.3 versus 7.3 during glucose fermentation under unregulated-pH conditions (RNA-seq data). Table S8. Acid stress response: transcriptional regulators and other regulatory proteins. Genes differentially regulated at acidic pH 6.3 versus 7.3 during glucose fermentation under unregulated-pH conditions (RNA-seq data). Table S9. Acid stress response: activation of sporulation. Genes differentially regulated at acidic pH 6.3 versus 7.3 during glucose fermentation under unregulated-pH conditions (RNA-seq data).

Additional file 5: 2D-DIGE data. Table S10. Protein identification table generated with the Biotools software (Bruker) using the Mascot search engine on the Clostridium butyricum 5521 protein database. Table S11. Proteins identified as differentially abundant in C. butyricum CWBI 1009 in response to the decline in $\mathrm{pH}$ during unregulated-pH glucose fermentation (2D-DIGE analysis).

Additional file 6: Argon discussion. Figure S4. Characteristics of the glucose fermentation for Clostridium butyricum CWBI 1009 performed under unregulated-pH conditions and $\mathrm{Ar}$ atmosphere. Figure S5. Relative expression of [FeFe] hydrogenases and nifH genes determined by RT-qPCR. Western blot analysis for NifH subunit of Clostridium butyricum CWBI 1009 during unregulated-pH glucose fermentation under $\mathrm{N}_{2}$ and Ar atmospheres. Table S13. Bioreactor performance of Clostridium butyricum CWBI 1009 cultivated in a 20L batch bioreactor with glucose (10 g/L) under unregulated-pH conditions and $\mathrm{N}_{2}$ or Ar atmospheres.

\section{Abbreviations}

2D-DIGE: Two-dimensional difference in gel electrophoresis; CDS: Coding DNA sequence; NFOR: NADH-ferredoxin oxidoreductase; PEP: Phosphoenolopyruvate; PFOR: Pyruvate-ferredoxin oxidoreductase; RPKM: Reads per kilobase per million mapped reads; RT-qPCR: Reverse transcription quantitative real-time PCR.

\section{Competing interests}

The authors declare that they have no competing interests.

\section{Authors' contributions}

MC designed the experiments, carried out the molecular genetic studies, analysed the data and drafted the manuscript. $\mathrm{CH}$ designed the experiments, carried out the fermentations and the 2D-DIGE study, analysed the data and drafted the manuscript. PM analysed the RNA-seq data and helped to draft the manuscript. GM participated in the 2D-DIGE study and helped to analyse the data. NL, FF, BJ and SH helped to design the experiments and coordinated the study. PT and AW conceived the study and participated in its design and coordination, and helped to draft the manuscript. All authors read and approved the final manuscript.

\section{Acknowledgements}

The research was funded by an ARC project (Action de Recherche Concertée, ARC -07/12-04), granted by the French Community of Belgium. A. Wilmotte is Research Associate of the FRS-FNRS of Belgium. We thank Pierre Leprince from the University of Liège for his assistance during the protein spots picking procedure. We would also like to acknowledge Julien Masset and Laurent Beckers from the University of Liège for their advice concerning the anaerobic fermentations and Gregory Hex for his advice in proteomics. We would like to thank lan Hamilton for his English correction of the manuscript.

\section{Author details}

${ }^{1}$ Centre for Protein Engineering, Bacterial Physiology and Genetics, University of Liège, Allée de la Chimie 3, B-4000 Liège, Belgium. 'Walloon Centre of Industrial Biology, University of Liège, Boulevard du Rectorat 29, B-4000 Liège, Belgium. ${ }^{3}$ Microbiology Unit, Expertise Group for Molecular and Cellular Biology, Institute for Environment, Health and Safety, Belgian Nuclear Research Centre (SCK-CEN), Boeretang 200, B-2400 Mol, Belgium.

${ }^{4}$ Bioenergetics Laboratory, University of Liège, Boulevard du Rectorat 27, B-4000 Liège, Belgium. ${ }^{5}$ Environmental Research and Innovation Department, Luxembourg Institute of Science and Technology, Rue du Brill 41, L-4422 Belvaux, Luxembourg.

Received: 12 September 2014 Accepted: 12 January 2015 Published online: 22 February 2015

\section{References}

1. Lens P, Westermann P, Haberbauer M, Moreno A. Biofuels for fuel cells: renewable energy from biomass fermentation. IWA Publishing; 2005

2. Hallenbeck PC. Microbial paths to renewable hydrogen production. Biofuels. 2011;2:285-302.

3. Hallenbeck PC, Ghosh D. Improvements in fermentative biological hydrogen production through metabolic engineering. J Environ Manag. 2012;95, Supplement:S360-4.

4. Levin DB, Pitt L, Love M. Biohydrogen production: prospects and limitations to practical application. Int J Hydrogen Energ. 2004;29:173-85.

5. Vignais PM, Colbeau A. Molecular biology of microbial hydrogenases. Curr Issues Mol Biol. 2004;6:159-88.

6. Calusinska M, Happe $T$, Joris B, Wilmotte $A$. The surprising diversity of clostridial hydrogenases: a comparative genomic perspective. Microbiology. 2010;156:1575-88.

7. Carnahan JE, Mortenson LE, Mower HF, Castle JE. Nitrogen fixation in cell-free extracts of Clostridium pasteurianum. Biochim Biophys Acta. 1960:44:520-35.

8. Chen JS, Toth J, Kasap M. Nitrogen-fixation genes and nitrogenase activity in Clostridium acetobutylicum and Clostridium beijerinckii. J Ind Microbiol Biotechnol. 2001;27:281-6.

9. Masset J, Hiligsmann S, Hamilton C, Beckers L, Franck F, Thonart P. Effect of $\mathrm{pH}$ on glucose and starch fermentation in batch and sequenced-batch 
mode with a recently isolated strain of hydrogen-producing Clostridium butyricum CWB11009. Int J Hydrogen Energ. 2010;35:3371-8.

10. Masset J, Calusinska M, Hamilton C, Hiligsmann S, Joris B, Wilmotte A, et al. Fermentative hydrogen production from glucose and starch using pure strains and artificial co-cultures of Clostridium spp. Biotechnol Biofuels. 2012;5:35.

11. Calusinska M, Joris B, Wilmotte A. Genetic diversity and amplification of different clostridial [FeFe] hydrogenases by group-specific degenerate primers. Lett Appl Microbiol. 2011;53:473-80.

12. Liu IC, Whang LM, Ren WJ, Lin PY. The effect of $\mathrm{pH}$ on the production of biohydrogen by clostridia: thermodynamic and metabolic considerations. Int J Hydrogen Energ. 2011;36:439-49.

13. Cai $G$, Jin B, Saint CP, Monis PT. Metabolic flux analysis of hydrogen production network by Clostridium butyricum W5: Effect of $\mathrm{pH}$ and glucose concentrations. Int J Hydrogen Energ. 2010;35:6681-90.

14. Wang Y, Li X, Mao Y, Blaschek H. Genome-wide dynamic transcriptional profiling in Clostridium beijerinckii NCIMB 8052 using single-nucleotide resolution RNA-Seq. BMC Genomics. 2012;13:102.

15. Alsaker KV, Paredes C, Papoutsakis ET. Metabolite stress and tolerance in the production of biofuels and chemicals: gene-expression-based systems analysis of butanol, butyrate, and acetate stresses in the anaerobe Clostridium acetobutylicum. Biotechnol Bioeng. 2010;105:1131-47.

16. Schwarz KM, Kuit W, Grimmler C, Ehrenreich A, Kengen SWM. A transcriptional study of acidogenic chemostat cells of Clostridium acetobutylicum - cellular behavior in adaptation to $n$-butanol. J Biotechnol. 2012;161:366-77.

17. Ma Y, Huang A, Zhu D, Pan G, Wang G. Biohydrogen production via the interaction of nitrogenase and anaerobic mixed-acid fermentation in marine bacteria. Int J Hydrogen Energ. 2015;40:176-83.

18. Burgess BK, Wherland S, Newton WE, Stiefel El. Nitrogenase reactivity: insight into the nitrogen-fixing process through hydrogen-inhibition and HD-forming reactions. Biochemistry. 1981;20:5140-6.

19. Igarashi RY, Seefeldt LC. Nitrogen fixation: the mechanism of the Mo-dependent nitrogenase. Crit Rev Biochem Mol Biol. 2003;38:351-84.

20. Yoch DC, Pengra RM. Effect of amino acids on the nitrogenase system of Klebsiella pneumoniae. J Bacteriol. 1966:92:618-22.

21. Slonczewski JL, Fujisawa M, Dopson M, Krulwich TA. Cytoplasmic pH measurement and homeostasis in bacteria and archaea. In: Robert KP, editor. Advances in microbial physiology. Volume 55. Academic Press; 2009:1-317.

22. Sachs G, Kraut JA, Wen Y, Feng J, Scott DR. Urea transport in bacteria: acid acclimation by gastric Helicobacter spp. J Membrane Biol. 2006;212:71-82.

23. Piper $P$, Mahe $Y$, Thompson S, Pandjaitan R, Holyoak C, Egner R, et al. The Pdr12 ABC transporter is required for the development of weak organic acid resistance in yeast. EMBO J. 1998;17:4257-65.

24. Wortham B, Oliveira M, Patel C. Polyamines in bacteria: pleiotropic effects yet specific mechanisms. In: Perry R, Fetherston J, editors. The genus Yersinia. 603rd ed. New York: Springer; 2007. p. 106-15.

25. Kusano T, Berberich T, Tateda C, Takahashi Y. Polyamines: essential factors for growth and survival. Planta. 2008;228:367-81.

26. Higgins $D$, Dworkin J. Recent progress in Bacillus subtilis sporulation. FEMS Microbiol Rev. 2012;36:131-48.

27. Dürre P. Handbook on Clostridia. 2005. Taylor \& Francis Group.

28. Vignais PM, Billoud B. Occurrence, classification, and biological function of hydrogenases: an overview. Chem Rev. 2007:107:4206-72

29. Bothe H, Schmitz O, Yates MG, Newton W: Nitrogenases and hydrogenases in cyanobacteria. In: Peschek GA, Obinger C, Renger G, editors. Bioenergetic processes of Cyanobacteria. Springer Netherlands; 2011. p. 137-157.

30. Schut GJ, Adams MWW. The iron-hydrogenase of Thermotoga maritima utilizes ferredoxin and NADH synergistically: a new perspective on anaerobic hydrogen production. J Bacteriol. 2009;191:4451-7.

31. Meyer J. Clostridial iron-sulphur proteins. J Mol Microbiol Biotechnol. 2000;2:9-14

32. White D. The physiology and biochemistry of prokaryotes. 3rd ed. New York: Oxford University Press; 2006.

33. Amon J, Titgemeyer F, Burkovski A. Common patterns - unique features: nitrogen metabolism and regulation in Gram-positive bacteria. FEMS Microbiol Rev. 2010;34:588-605

34. Adams MW, Mortenson LE. The physical and catalytic properties of hydrogenase II of Clostridium pasteurianum. A comparison with hydrogenase I. J Biol Chem. 1984;259:7045-55.
35. Kim DH, Lee JH, Kang S, Hallenbeck P, Kim EJ, Lee J, et al. Enhanced photo-fermentative $\mathrm{H}_{2}$ production using Rhodobacter sphaeroides by ethanol addition and analysis of soluble microbial products. Biotechnol Biofuels. 2014;7:79.

36. Oh EK, Kim EJ, Hwang HJ, Tong X, Nam JM, Kim MS, et al. The photoheterotrophic $\mathrm{H}_{2}$ evolution of Rhodobacter sphaeroides is enhanced in the presence of ethanol. Int J Hydrogen Energ. 2012;37:15886-92.

37. Hamilton C, Hiligsmann S, Beckers L, Masset J, Wilmotte A, Thonart P. Optimization of culture conditions for biological hydrogen production by Citrobacter freundii CWBI952 in batch, sequenced-batch and semicontinuous operating mode. Int J Hydrogen Energ. 2010;35:1089-98.

38. Li H, Durbin R. Fast and accurate short read alignment with BurrowsWheeler transform. Bioinformatics. 2009:25:1754-60.

39. Robinson MD, McCarthy DJ, Smyth GK. edgeR: a Bioconductor package for differential expression analysis of digital gene expression data. Bioinformatics. 2010;26:139-40.

40. Zerbino DR, Birney E. Velvet: algorithms for de novo short read assembly using de Bruijn graphs. Genome Res. 2008;18:821-9.

41. Savichtcheva O, Joris B, Wilmotte A, Calusinska M. Novel FISH and quantitative PCR protocols to monitor artificial consortia composed of different hydrogen-producing Clostridium spp. Int J Hydrogen Energ. 2010;36:7530-42

42. Rasmussen R. Quantification on the LightCycler. In: Meuer S, Wittwer C, Nakagawara K, editors. Rapid cycle real-time PCR, methods and applications. Heidelberg: Springer Press; 2001. p. 21-34.

43. Pfaffl MW, Horgan GW, Dempfle L. Relative expression software tool (REST-๑) for group-wise comparison and statistical analysis of relative expression results in real-time PCR. Nucleic Acids Res. 2002;30:e36.

44. Ellefsen S, Stenslekken KO, Sandvik GK, Kristensen TA, Nilsson GE. Improved normalization of real-time reverse transcriptase polymerase chain reaction data using an external RNA control. Anal Biochem. 2008;376:83-93.

45. Pfaffl M, Tichopad A, Prgomet C, Neuvians T. Determination of stable housekeeping genes, differentially regulated target genes and sample integrity: BestKeeper-Excel-based tool using pair-wise correlations. Biotechnol Lette. 2004:26:509-15.

46. Gorg A, Weiss W, Dunn MJ. Current two-dimensional electrophoresis technology for proteomics. Proteom. 2004:4:3665-85.

47. Shevchenko A, Jensen ON, Podtelejnikov A, Sagliocco F, Wilm M, Vorm O, et al. Linking genome and proteome by mass spectrometry: Large-scale identification of yeast proteins from two dimensional gels. Proc Natl Acad Sci U S A. 1996;93:14440-5.

\section{Submit your next manuscript to BioMed Central and take full advantage of:}

- Convenient online submission

- Thorough peer review

- No space constraints or color figure charges

- Immediate publication on acceptance

- Inclusion in PubMed, CAS, Scopus and Google Scholar

- Research which is freely available for redistribution 